This document is confidential and is proprietary to the American Chemical Society and its authors. Do not copy or disclose without written permission. If you have received this item in error, notify the sender and delete all copies.

\title{
Formal Total Synthesis of Amphidinolide E
}

\begin{tabular}{|r|l|}
\hline Journal: & The Journal of Organic Chemistry \\
\hline Manuscript ID & jo-2017-01973x.R1 \\
\hline Manuscript Type: & Article \\
\hline Date Submitted by the Author: & $21-$ Sep-2017 \\
\hline Complete List of Authors: & $\begin{array}{l}\text { Bosch, Lluís; University of Barcelona, Organic Chemistry Section, } \\
\text { Mola, Laura; Universitat de Barcelona, Organic Chemistry Section, } \\
\text { Petit, Elena; Universitat de Barcelona, Organic Chemistry Section, } \\
\text { Saladrigas, Mar; University of Barcelona, Organic Chemistry Section, } \\
\text { Esteban, Jorge; Universitat de Barcelona, Organic Chemistry Section } \\
\text { Costa, Anna; Universitat de Barcelona, Organi Chemistry Section, } \\
\text { Vilarrasa, Jaume; University of Barcelona, Organic Chemistry Section, }\end{array}$ \\
\hline
\end{tabular}

\section{SCHOLARONE}

Manuscripts 


\title{
Formal Total Synthesis of Amphidinolide E
}

\author{
Lluís Bosch, Laura Mola, Elena Petit, Mar Saladrigas, Jorge Esteban, Anna M. Costa,* and Jaume Vilarrasa* \\ Organic Chemistry Section, Facultat de Química, Universitat de Barcelona, Diagonal 645, 08028 Barcelona, Catalonia, Spain
}

Supporting Information

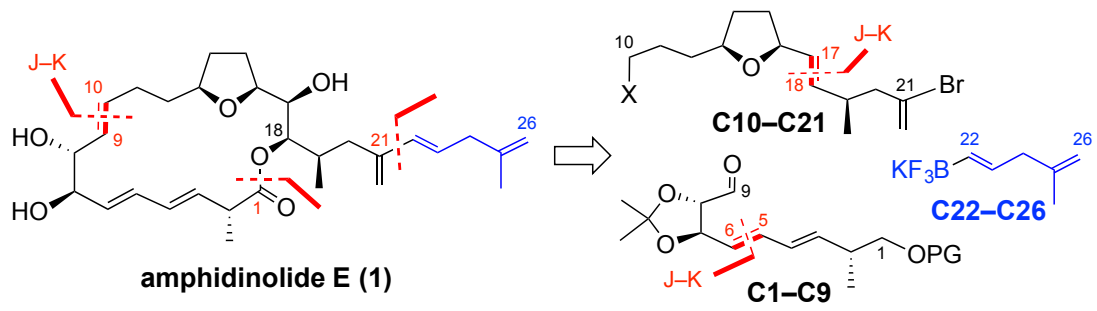

\begin{abstract}
A formal total synthesis of the cytotoxic macrolide amphidinolide E is reported. The strategic steps are three JuliaKocienski reactions $(\mathrm{J}-\mathrm{K})$, for the formation of the C5-C6, C9-C10, and C17-C18 double bonds, a Suzuki-Molander C21-C22 bond formation reaction, and a Kita-Trost macrolactonization. The "instability" of the two dienic systems and of the stereocenter at $\mathrm{C} 2$ (allylic methine, $\alpha$ to the carboxy group) and the protecting groups at $\mathrm{C} 17-\mathrm{OH}$ and $\mathrm{C} 18-\mathrm{OH}$ have posed difficult challenges. Each JuliaKocienski olefination has been systematically optimized to provide the highest possible $E / Z$ ratios.
\end{abstract}

\section{INTRODUCTION}

The amphidinolides are a family of complex macrolides isolated from cultured marine dinoflagellates of the genus Amphidinium $s p$. , which live off the coasts of Okinawa Island (Japan). ${ }^{1}$ Some years ago we engaged in a research program directed towards the total synthesis and elucidation of the biological mechanism of action of several members of this family of natural products. ${ }^{2}$ As part of this research effort we now report a formal total synthesis of amphidinolide E (1), a cytotoxic 19-membered macrolactone with an embedded tetrahydrofuran ring, eight stereocenters, two conjugated dienes and a unique side chain. The isolation of $\mathbf{1}$ was reported by Kobayashi et al. in $1990^{3 \mathrm{a}}$ while its absolute stereochemistry was determined in $2002^{3 \mathrm{~b}}$ and was later confirmed by two total syntheses from the groups of Lee ${ }^{4}$ and Roush. ${ }^{5}$ The preparation of several fragments has also been reported by other authors. ${ }^{6}$ The strategy of Lee et al. ${ }^{4}$ involved the formation of the oxolane (tetrahydrofuran) ring by a radical cyclization (formation of the $\mathrm{C} 13-\mathrm{C} 14$ bond), an enyne Ru-catalyzed reaction with 2-methyl-1,4-pentadiene to generate the C22-C23 double bond, and a final macrolactonization step. The strategy of $\mathrm{Va}$ and Roush ${ }^{5}$ was based in the formation of the oxolane ring of $\mathbf{1}$ by an annulation reaction of an aldehyde (C5/6-C13), arising from tartaric acid, and an allylsilane (C14-C21/29) with a terminal triple bond between $\mathrm{C} 21$ and C29, arising from L-glyceraldehyde; the C5-C6 double bond was installed by means of a RCM, but the requirement of a conjugate diene $\mathrm{C} 1-\mathrm{C} 5 / 6$ forced the authors to protect it as a $\mathrm{Fe}(\mathrm{CO})_{3}$ complex in the previous step. Part of the side chain (C22-C26) was added in the last step by means of a Stille coupling, after the RCM reaction. 
Our retrosynthetic analysis of $\mathbf{1}$ is different, although it shares with the strategy of Lee et al. ${ }^{4}$ the macrolactonization step and one Julia-Kocienski reaction (henceforward, J-K reaction) to create the C9-C10 double bond. As shown in Scheme 1, our retrosynthesis disconnects the molecule into three fragments: the southern fragment $(\mathrm{C} 1-\mathrm{C} 9)$, the northern fragment $(\mathrm{C} 10-\mathrm{C} 21)$ and the side chain $(\mathrm{C} 22-\mathrm{C} 26) .{ }^{6 \mathrm{~d}}$ The $\mathrm{C} 10-\mathrm{C} 21$ fragment can be accessed through a J-K reaction between aldehyde $\mathrm{C} 10-\mathrm{C} 17$ and sulfone $\mathrm{C} 18-\mathrm{C} 21$, followed by a Sharpless dihydroxylation of the newly formed double bond. Another J-K reaction was also chosen to assemble the $\mathrm{C} 1-\mathrm{C} 9$ fragment, by reaction of aldehyde $\mathrm{C} 6-\mathrm{C} 9$, derived from tartaric acid, and sulfone $\mathrm{C} 1-\mathrm{C} 5$, prepared using a procedure described previously by some of us. ${ }^{6 c}$ Although there are several possibilities to link the appropriate fragments of such a demanding structure with two conjugate dienes and two additional double bonds, we planned to apply three J-K reactions, which would require a fine tuning of the reaction conditions to overcome the difficulties that undoubtedly would appear.

\section{Scheme 1. Retrosynthetic Analysis of Amphidinolide E (1)}

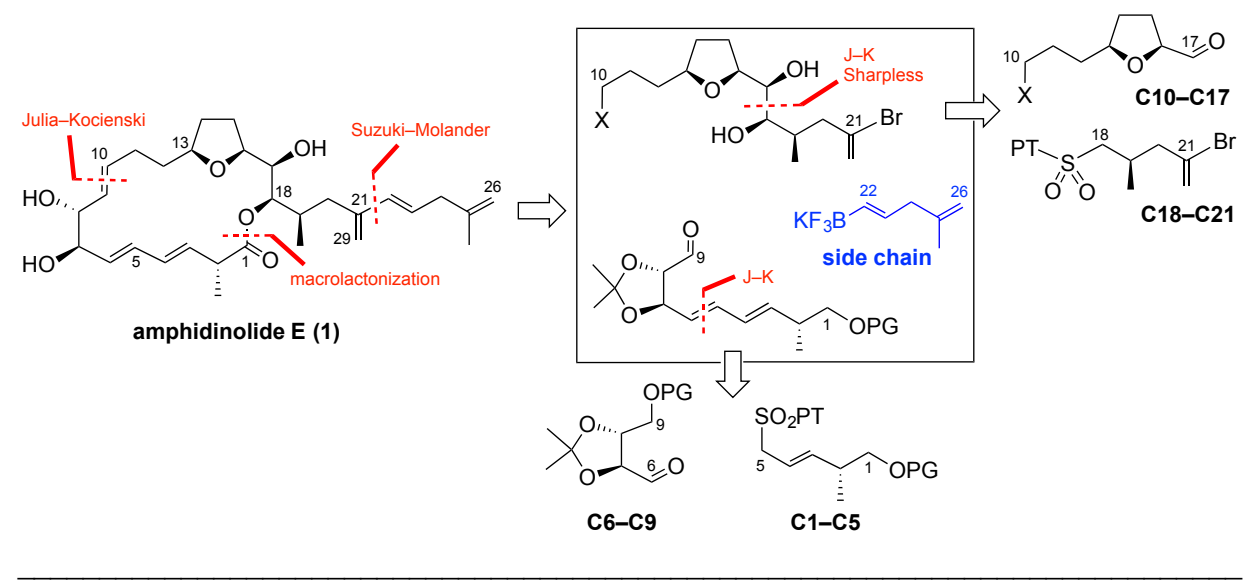

\section{RESULTS AND DISCUSSION}

Preparation of the southern fragment (C1-C9). For the synthesis of fragment $\mathrm{C} 1-\mathrm{C} 9$ we envisaged the formation of the C5-C6 bond via a $\mathrm{J}-\mathrm{K}$ reaction. This transformation has been a useful tool for the construction of 1,3-dienes present in complex natural products. $^{7}$ These moieties can either be accessed by a J-K reaction between an aliphatic sulfone and an $\alpha, \beta$-unsaturated aldehyde or that between an allylic sulfone and an aliphatic aldehyde. Both alternatives have been widely employed, with the former consistently providing a new $E$ double bond, whereas the diastereoselectivity of the reaction of allylic sulfones is uncertain, ${ }^{7}$ although a recent study has helped rationalize the experimental outcome of these reactions. ${ }^{8}$ We initially explored the first strategy, with discouraging results. ${ }^{9}$ Thus, we then focused on the reaction of sulfone $\mathrm{C} 1-\mathrm{C} 5$ (PG = TBDPS) with aldehyde C6-C9 (PG = TES).

As shown in Scheme 2, the reduction of dimethyl $(S, S)$-tartrate (2) to the corresponding diol, followed by monoprotection as triethylsilyl (TES) ether (3) ${ }^{10}$ and oxidation with the Dess-Martin periodinane (DMP), gave the desired aldehyde 4 (fragment C6-C9). 
Scheme 2. Preparation of Aldehyde C6-C9

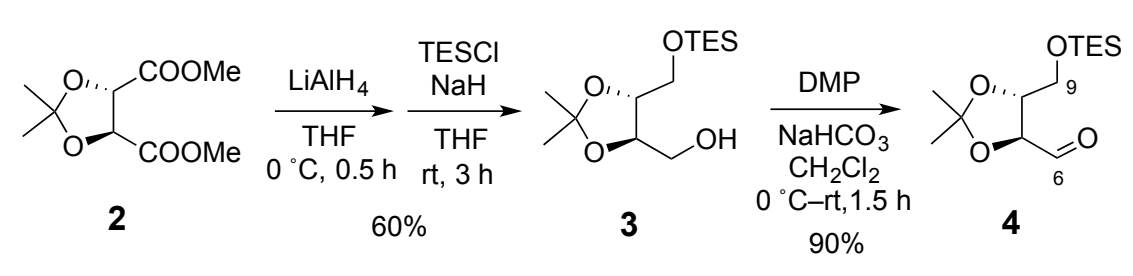

Alcohol 5, previously prepared by us via a Michael addition-elimination reaction of a chiral enolate to ethyl 3-iodoacrylate, ${ }^{6 c}$ was the starting point for the preparation of the next fragment (sulfone C1-C5 in Scheme 1, see 9 in Scheme 3). A Mitsunobu reaction with 1-phenyl-1H-tetrazole-5-thiol (henceforward, PT-SH or PTSH) ${ }^{11}$ converted the alcohol into thioether 6. Elimination of the chiral auxiliary with $\mathrm{NaBH}_{4}$ in $\mathrm{THF}-\mathrm{H}_{2} \mathrm{O}$ and protection of the resulting alcohol 7 as TBDPS ether 8 proceeded uneventfully.

Oxidation of this allylic thioether under standard conditions (10 equiv $\mathrm{H}_{2} \mathrm{O}_{2}, 20 \mathrm{~mol} \%$ of heptamolybdate ion) afforded poor yields of the desired sulfone (9) with isolation of substantial amounts of 9a, a mixture of known syn and anti allylic alcohols in a quite similar ratio $\left({ }^{1} \mathrm{H}\right.$ NMR spectrum), arising from a [2,3]-sigmatropic rearrangement of the intermediate allylic sulfoxide and subsequent hydrolysis of the allyl sulfenate. This is a known undesired reaction in the preparation of allylic heteroaryl sulfones. ${ }^{12}$ To increase the oxidation rate of the allylic sulfoxide to sulfone, relative to the [2,3]-sigmatropic rearrangement, both the equivalents of $\mathrm{H}_{2} \mathrm{O}_{2}$ and catalyst were raised. In our case, with 30 equiv of $\mathrm{H}_{2} \mathrm{O}_{2}$ and 40 mol \% of heptamolybdate ion, the desired sulfone was obtained in $88 \%$ yield, with minimal formation of alcohol 9a (9:1 9/9a ratio). Attempts to further improve this ratio by increasing the amount of reagents, by very slowly adding 8 in EtOH to the aqueous yellow solution of $\left(\mathrm{NH}_{4}\right)_{6} \mathrm{Mo}_{7} \mathrm{O}_{24} / \mathrm{H}_{2} \mathrm{O}_{2}$, by lowering the temperature, and/or by changing the medium acidity were not successful.

\section{Scheme 3. Synthesis of Sulfone 9}

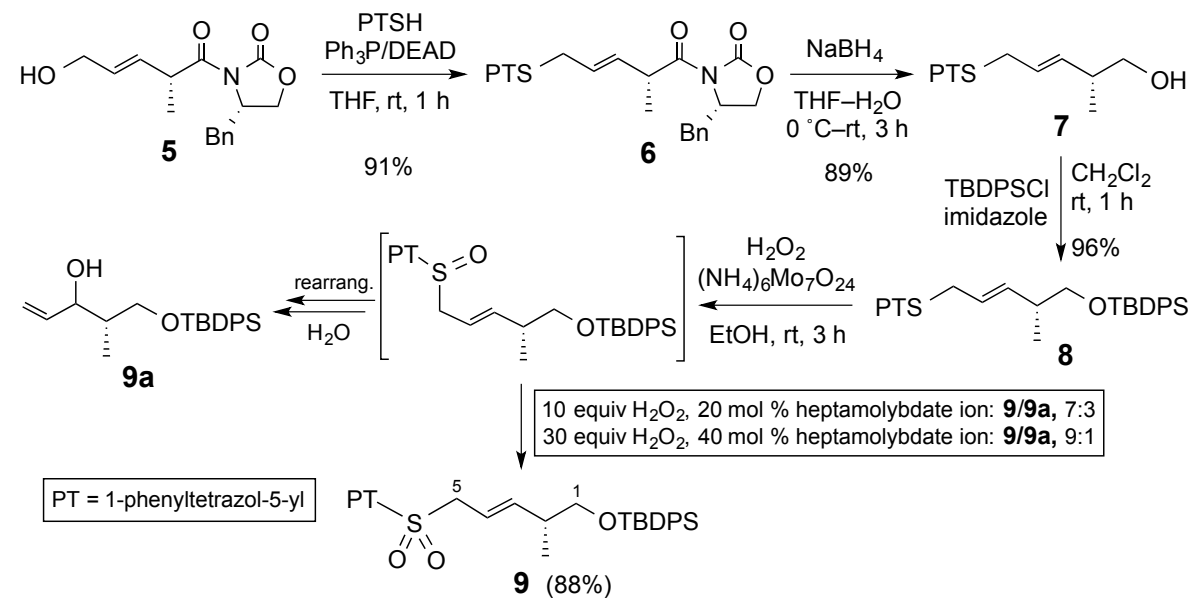


We were now ready to explore the J-K reaction between sulfone 9 and aldehyde 4 for the formation of the C5-C6 bond (Scheme 4). Our first attempts (KHMDS, DMF, from $-65^{\circ} \mathrm{C}$ to rt, $18 \mathrm{~h}$ ) afforded complex reaction mixtures. We soon noted that the TES group was being cleaved under the reaction conditions and that shortening the reaction time from $18 \mathrm{~h}$ to $4 \mathrm{~h}$ avoided this side reaction and furnished the desired $(3 E, 5 E)$-diene 10, together with the (3E,5Z)-diene and an unexpected isomer in a 57:17:26 ratio. Characterization of this unexpected product was hampered by the impossibility to separate it completely from the (3E,5E)- and $(3 E, 5 Z)$-isomers by flash column chromatography. However, by comparison of the ${ }^{1} \mathrm{H}$ NMR spectra of pure samples of these isomers with reaction mixtures, we eventually identified it as the (3Z,5E)-diene. ${ }^{13}$ This isomer can arise from $E$ to $Z$ isomerization of the allylic sulfone anion during the reaction. ${ }^{14}$

After some experimentation we could maximize the yield of (3E,5E)-10 using an excess of base (2.5 equiv of solid KHMDS) and aldehyde (1.2 equiv) in the presence of 18 -crown-6 (which is known to increase the formation of the $E$ isomer), ${ }^{15}$ under Barbier-like conditions, in DMF below $-40^{\circ} \mathrm{C}$. In this way, the product was obtained in good yield as an 82:13:5 mixture of diastereoisomers. An attempt using KH, instead of KHMDS, also afforded an 80\% isolated yield but of a 75:8:17 mixture. Attempts to isomerize these diastereomeric mixtures, aimed at increasing the ratio of the $E$,E-isomer, with $\mathrm{I}_{2}$ and with $\left.\mathrm{PdCl}_{2}\left(\mathrm{NCCH}_{3}\right)_{2}\right)$, were unsuccessful.

\section{Scheme 4. Formation of the C5-C6 Double Bond}

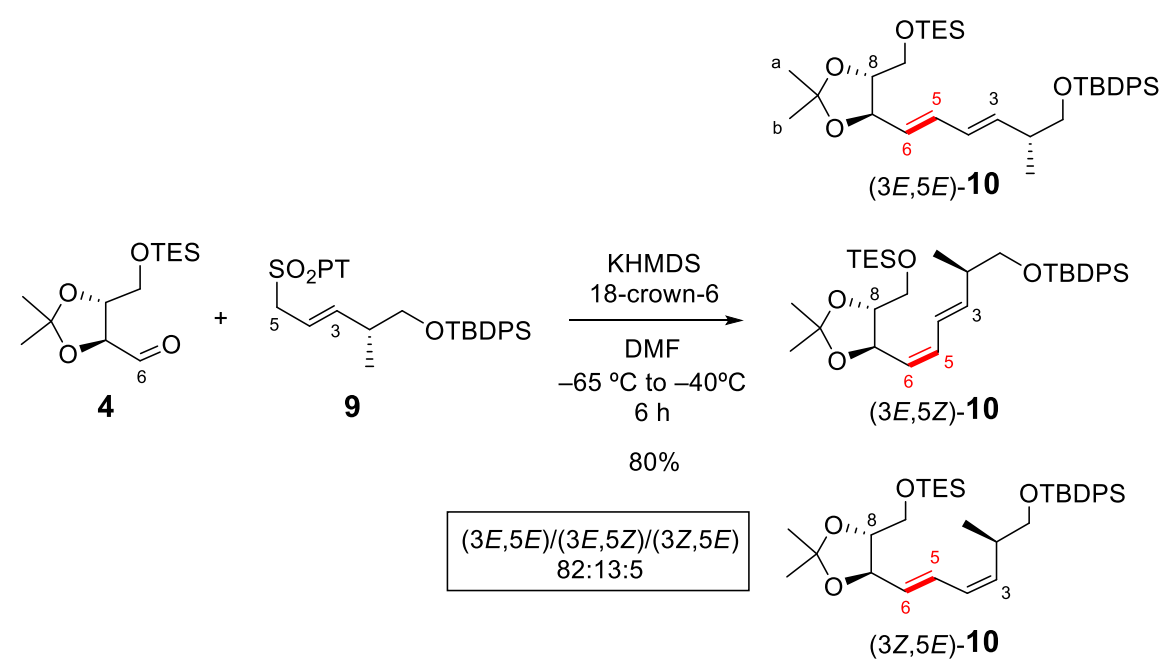

Because of the difficulty of completely separating the different diastereomers of $\mathbf{1 0}$, the mixture was treated with ethanol and pyridinium $p$-toluenesulfonate (PPTS) to furnish the expected alcohols 11 (see Scheme 5). At this stage, the $E$,E-isomer (ca. 65\% overall yield for the J-K olefination and the deprotection step) could be isolated by flash chromatography; ca. $10 \%$ of the so-called ( $3 E, 5 Z)-11$ in Scheme 5 was also separated. Oxidation of ( $3 E, 5 E)$-11 with DMP allowed us to isolate the desired aldehyde 12 (stereopure) in excellent yield (see Supporting Information for the comparison of the main ${ }^{1} \mathrm{H}$ NMR data and the Experimental Section for ${ }^{13} \mathrm{C}$ NMR spectra). 


\section{Scheme 5. Isolation of 11 and Preparation of Aldehyde 12 (Fragment C1-C9)}

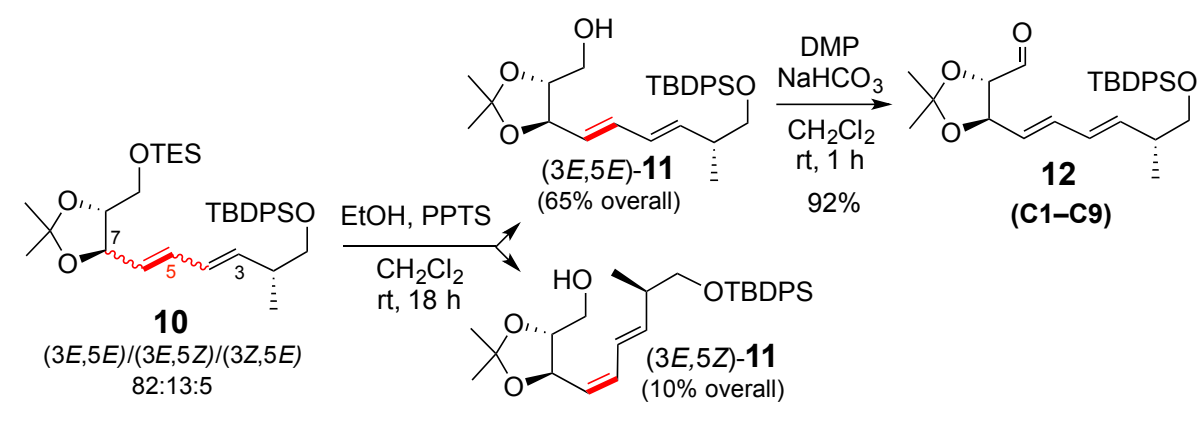

Synthesis of the northern fragment $(\mathbf{C 1 0}-\mathbf{C} 21)$. The synthesis of the $\mathrm{C} 10-\mathrm{C} 21$ fragment via a $\mathrm{J}-\mathrm{K}$ reaction between sulfone $\mathrm{C} 10-\mathrm{C} 17$ and aldehyde $\mathrm{C} 18-\mathrm{C} 21$ was described by some of us several years ago. ${ }^{6 \mathrm{~d}}$ In practice, we had obtained the tetrahydrofuran derivative (oxolane C10-C17) from a butyrolactone (the allylsilyloxy derivative shown in Scheme 6, top) via an intramolecular allylation of the $\mathrm{TiCl}_{4}$-generated oxocarbenium ion, which afforded the desired 2,5-disubstituted oxolane in 70\% yield as a 85:15 cis/trans mixture. ${ }^{16}$ Although reliable, this route presented several drawbacks when gram-scale amounts of $\mathrm{C} 10-\mathrm{C} 17$ were needed. The intramolecular allylation ${ }^{16}$ required working under high-dilution conditions $\left(5 \cdot 10^{-3} \mathrm{M}\right)$ and the separation of the cis/trans diastereomers was extremely tedious. Thus, we decided to build up the C10-C17 fragment via alternative routes (Scheme 6, bottom).

\section{Scheme 6. Alternative Disconnections of Fragment C10-C21}

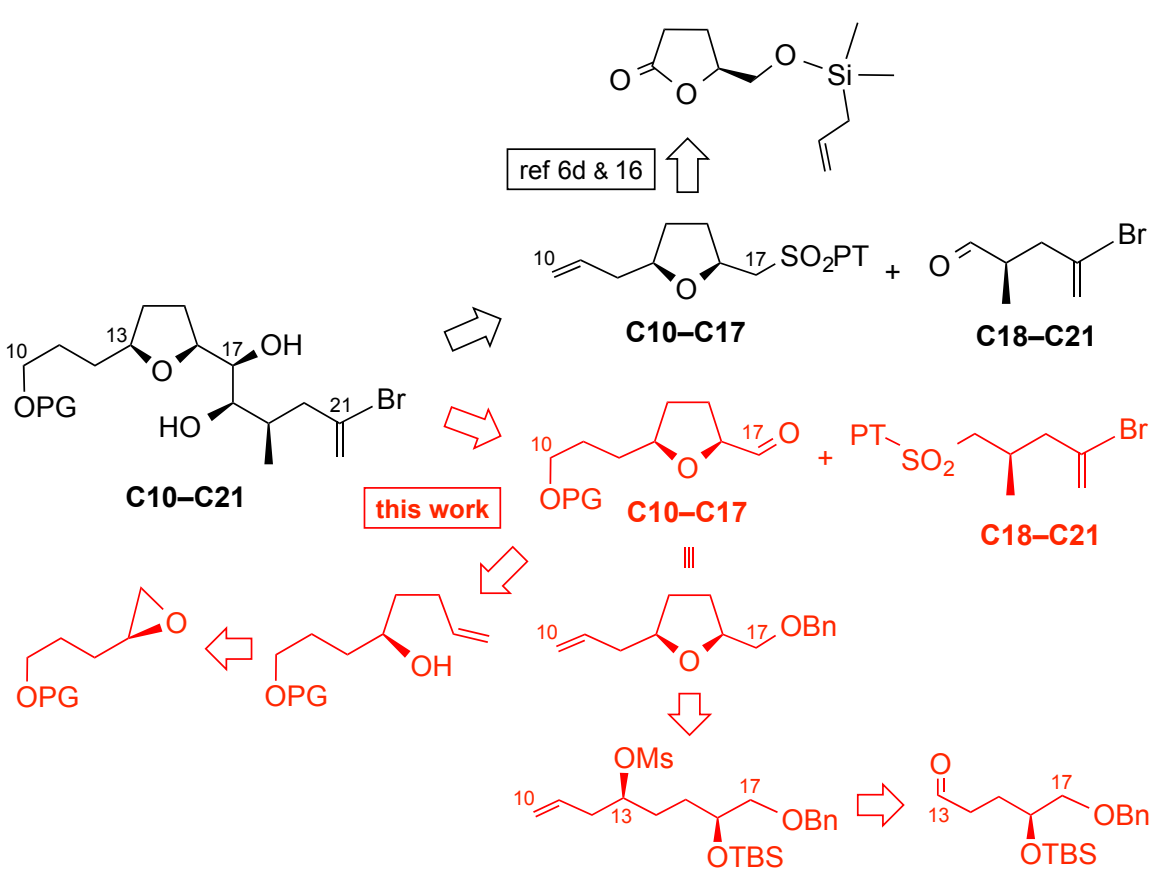


First, the synthesis of aldehyde C10-C17 began with 4-penten-1-ol, protected as its TBDPS derivative (13), which was epoxidized using Berkessel's catalyst (Scheme 7). We prepared it from $\operatorname{Ti}\left(\mathrm{O}^{\mathrm{i}} \mathrm{Pr}\right)_{4}$ and $c i s$-salalen according to the procedure reported. ${ }^{17 a, b} \mathrm{We}$ obtained the desired epoxide $\mathbf{1 4}$ in 90\% yield with 96:4 e.r. after 3 days of reaction by using 18 equiv of $\mathrm{H}_{2} \mathrm{O}_{2}$. The new catalyst of Berkessel et al., ${ }^{17 c}$ an analog with a binaphthyl substituent (see Scheme 7, bottom), afforded a better yield (98\%) and identical enantiopurity with 12 equiv of $\mathrm{H}_{2} \mathrm{O}_{2}$ within 2 days. Copper(I)-catalyzed ring opening of epoxide $\mathbf{1 4}$ with allylmagnesium bromide furnished alcohol 15, which was ready for a second epoxidation, this time using ent-cis-salalen, which we prepared as well. The epoxide cyclized in situ, to provide oxolane 16 as a $\geq 85: \leq 1: 7: 7$ mixture of stereoisomers, as determined by chiral HPLC, by comparison with a reference mixture of $( \pm)$-cis and $( \pm)$-trans isomers, prepared independently by epoxidation of the double bond with $m$-CPBA. Despite the excellent performance of these asymmetric epoxidation catalysts, the cis/trans ratio of the final product was practically identical to that obtained by means of the previous route. To date, no efforts have been made to improve the stereoselectivity of the last step(s), e.g. by protecting the $\mathrm{OH}$ group before the second epoxidation. Finally, the Swern oxidation (DMSO/ClCOCOCl, $\mathrm{CH}_{2} \mathrm{Cl}_{2},-78{ }^{\circ} \mathrm{C}$, then $\mathrm{Et}_{3} \mathrm{~N}$, from $-78{ }^{\circ} \mathrm{C}$ to $\left.0{ }^{\circ} \mathrm{C}\right)^{18}$ of $\mathbf{1 6}$ afforded the desired fragment $\mathrm{C} 10-\mathrm{C} 17$ (aldehyde 17) in 4 steps from $\mathbf{1 3}$ and an overall yield of $50 \%{ }^{19}$

\section{Scheme 7. Syntheses of 17 (Fragment C10-C17)}
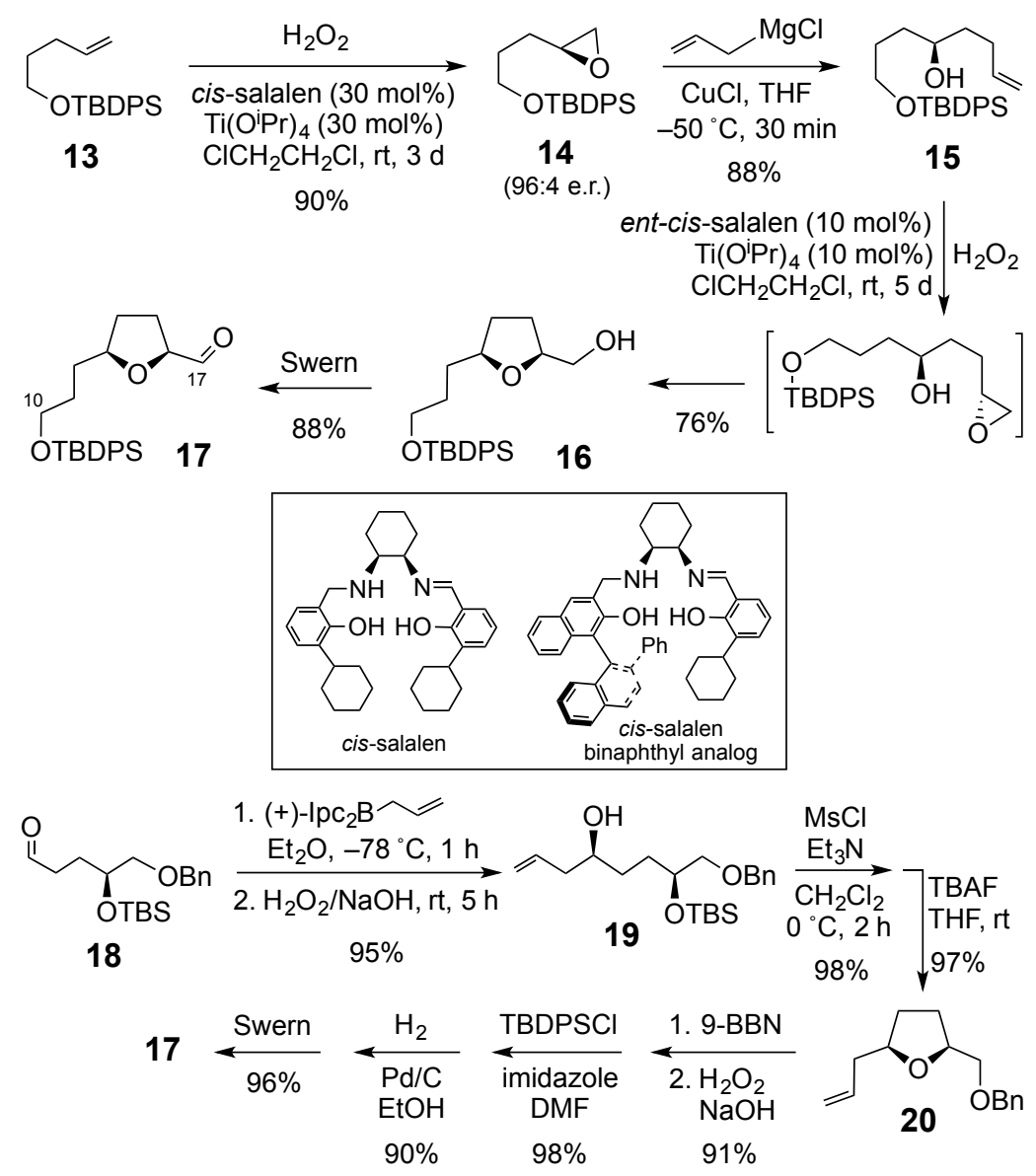
Another route, simpler but longer, was also examined, in order to avoid the cumbersome separation of the cis/trans mixture. Starting from chiroblock 18, a known compound, ${ }^{20}$ the sequence of standard high-yielding reactions shown in Scheme 7 (bottom) allowed us to obtain aldehyde $\mathbf{1 7}$ in a stereopure condition.

Fragment C18-C21 was synthesized from a known alcohol, 21. ${ }^{21}$ Preparation and isolation of 1-phenyltetrazol-5-yl sulfide 22 and its sulfone $\mathbf{2 3}$ did not pose any problem in this relatively simple case (Scheme 8).

\section{Scheme 8. Preparation of Sulfone 23}

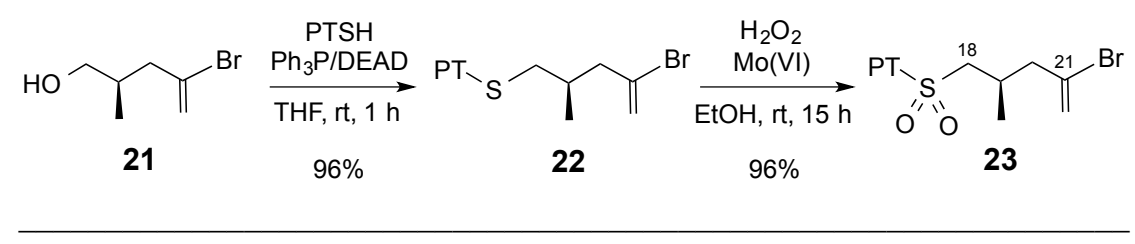

The optimization of the J-K coupling between this sulfone and aldehyde $\mathbf{1 7}$ (fragment C10-C17) is shown in Table 1, which summarizes around 25 experiments. The use of LiHMDS or NaHMDS in DMF, THF, or THF/HMPA (entries 1-4) was not encouraging. We confirmed the known fact ${ }^{6 \mathrm{~d}, 7,22}$ that polar coordinating solvents and large counter-ions, such as $\mathrm{K}^{+}$, favor the formation of the $E$ stereoisomers (entries 5 and 6). Addition of $\mathrm{HMPA}^{6 \mathrm{~d}}$ was detrimental to yield (entry 7). Use of solid KHMDS in DMF (entry 8) was not advantageous, probably due to solubility problems. We tried to further improve the outcome of the reaction by adding 18 -crown-6 as an additive ${ }^{15}$ (entry 9), but no advantages were noted in this particular case. Finally, an increase of the reaction scale allowed us to lower the amount of sulfone (entry 11) and to achieve the best yield.

Table 1. Optimization of the Julia-Kocienski Reaction between 23 and 17

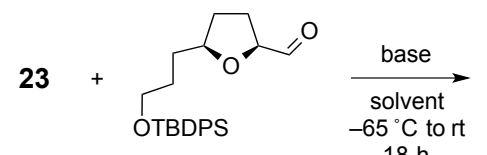

17

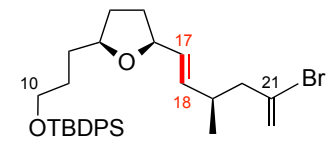

24

$\begin{array}{clcccc}\text { entry } & \text { base (equiv) } & \text { equiv of } \mathbf{2 3} & \text { solvent/additive } & \begin{array}{c}\text { yield of } \\ \mathbf{2 4}(\mathbf{\%})\end{array} & E / Z^{\boldsymbol{a}} \\ 1 & \text { LiHMDS in THF (2.0) } & 2.1 & \text { DMF } & 62 & 83: 17 \\ 2 & \text { NaHMDS in THF (1.1) } & 1.2 & \text { THF } & 55 & 50: 50 \\ 3 & \text { NaHMDS in THF (1.1) } & 1.2 & \text { DMF } & 26 & 89: 11 \\ 4 & \text { NaHMDS in THF (2.0) } & 2.1 & \text { THF/HMPA } & 60 & \mathbf{7 5 : 2 5} \\ 5 & \text { KHMDS in toluene (1.2) } & 1.1 & \text { DMF } & 54 & 95: 5 \\ 6 & \text { KHMDS in toluene (2.0) } & \mathbf{2 . 1} & \text { DMF } & \mathbf{7 4} & \mathbf{9 5 : 5} \\ 7 & \text { KHMDS in toluene (2.0) } & 2.1 & \text { DMF/HMPA } & 65 & 95: 5 \\ 8 & \text { Solid KHMDS (2.0) } & 2.1 & \text { DMF } & 69 & 92: 8 \\ 9 & \text { KHMDS in toluene (2.0) } & \mathbf{2 . 1} & \text { DMF/18-crown-6 } & \mathbf{7 2} & \mathbf{9 6 : 4} \\ 10^{\boldsymbol{d}} & \text { KHMDS in toluene (1.5) } & \mathbf{1 . 6} & \text { DMF } & \mathbf{8 0} & \mathbf{9 6 : 4}\end{array}$

${ }^{a} E / Z$ ratios were determined by ${ }^{1} \mathrm{H}$ NMR (400 MHz). Reactions with $0.10-0.15 \mathrm{mmol}$ of 17, unless otherwise indicated. Isolated yields of the $E / Z$ mixtures are referred to 17 , which is the substrate more "expensive" and difficult to recover. ${ }^{b}$ A modified Julia reaction, with the benzothiazol-2-yl group instead of the 1-phenyltetrazol-5-yl group, gave a similar yield but lower stereoselectivity (87:13 $E / Z$ ). ${ }^{c}$ With 2.0 equiv of 18 -crown-6. ${ }^{d}$ At 0.73 -mmol scale. 
With oxolane 24 in our hands, we completed the synthesis of the northern fragment as shown in Scheme 9. Sharpless asymmetric dihydroxylation of $\mathbf{2 4}$ with AD-mix- $\beta$ provided syn-diol $\mathbf{2 5}$ and its diastereomeric syn-diol in a 93:7 ratio. Diastereomerically pure $\mathbf{2 5}$ was isolated in $85 \%$ yield after flash column chromatography. Protection of the 1,2-diol of $\mathbf{2 5}$ as the $p$ methoxybenzyl acetal (26, ca. 1:1 mixture of epimers) and selective cleavage of this acetal with DIBALH afforded $\mathbf{2 7}$ in excellent yield. The resulting alcohol was protected as its MOM ether (with methoxymethyl chloride, NaI, and diisopropylethylamine) and the primary O-TBDPS group was cleaved with TBAF. ${ }^{23}$ Conversion to the sulfone was carried out as in the preceding examples. The synthesis of the required $\mathrm{C} 10-\mathrm{C} 27$ fragment, 28, was completed by deprotection of the PMB ether with 2,3-dichloro-5,6-dicyano-1,4benzoquinone (DDQ) and water.

\section{Scheme 9. Completion of the Synthesis of the Northern Fragment}

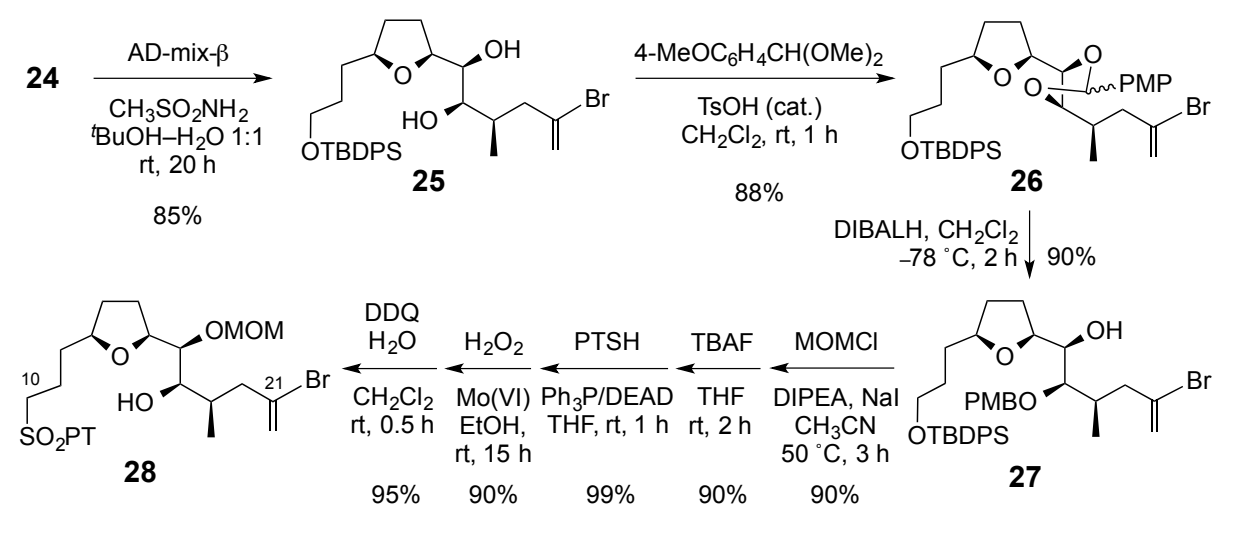

The end-game. With the $\mathrm{C} 1-\mathrm{C} 9$ and $\mathrm{C} 10-\mathrm{C} 21$ fragments in our hands, as well as with the side chain $(\mathrm{C} 22-\mathrm{C} 26),{ }^{6 \mathrm{~d}}$ we were ready to tackle the final steps of the synthesis of amphidinolide E. After considering different approaches, ${ }^{24}$ we decided to first form the $\mathrm{C} 9-\mathrm{C} 10$ bond by means of a $\mathrm{J}-\mathrm{K}$ reaction. Initially, we attempted the $\mathrm{J}-\mathrm{K}$ reaction of sulfone $\mathbf{2 8}$ with aldehyde $\mathbf{1 2}$, hoping to avoid the protection of the $\mathrm{C} 18$ alcohol (using $\geq 2$ equiv of base). However, all the conditions tested afforded poor yields and diastereoselectivities of the desired product.

Therefore, $\mathbf{2 8}$ was protected as $\mathbf{2 9}$. We systematically examined its $\mathrm{J}-\mathrm{K}$ reaction with aldehyde $\mathbf{1 2}$ (Scheme 10). Much to our dismay, conversions below $30 \%$ with loss of $\mathbf{1 2}$ were noted in the first attempts with KHMDS/18-crown- $6 .{ }^{25}$ This J-K reaction, with two highly functionalized fragments, was really more challenging than the previous ones. As we observed in blank experiments that sulfone 29 survived under the conditions of Scheme 10, we used an excess of it (2 equiv) and of KHMDS and 18-crown-6 (1.7 equiv, both). In this way, olefin $\mathbf{3 0}$ was isolated as a single stereoisomer in $68 \%$ yield. Most of the excess of $\mathbf{2 9}$ could be recovered. 


\section{Scheme 10. Union of the Three Fragments}

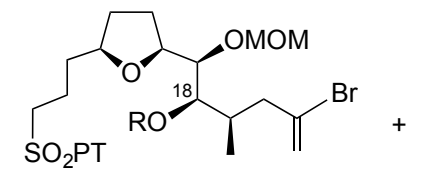

29, $R=$ TBDPS

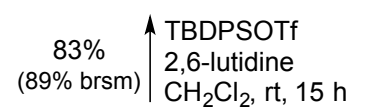

28, $R=H$

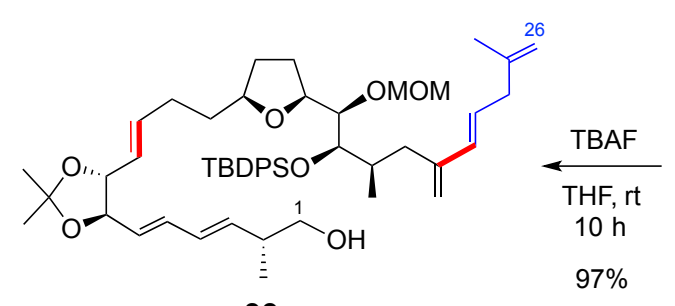

33

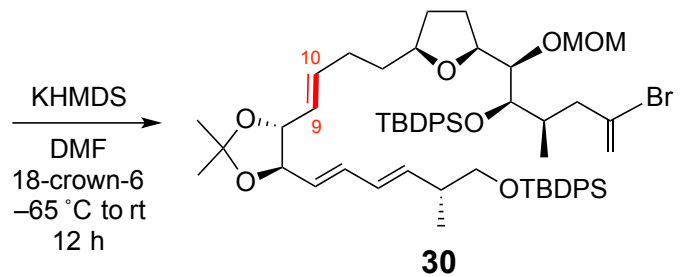

$68 \%$

With such a high-MW polyfunctional substrate, the Suzuki-Molander reaction of $\mathbf{3 0}$ with organotrifluoroborate $\mathbf{3 1}^{6 \mathrm{~d}}$ gave no conversion under standard conditions $\left[5 \mathrm{~mol} \% \mathrm{Pd}(\mathrm{OAc})_{2}, 10 \mathrm{~mol} \% \mathrm{Ph}_{3} \mathrm{P}, 3\right.$ equiv $\left.\mathrm{Cs}_{2} \mathrm{CO}_{3}\right]{ }^{26}$ However, an excellent yield of 32 was eventually obtained (95\%, Scheme 10) when both the amount of catalyst and phosphine was increased and an excess of 31 (2.5 equiv) was used. Selective cleavage of the TBDPS ether of the primary alcohol of $\mathbf{3 2}$ with TBAF afforded $\mathbf{3 3}$ in excellent yield, without touching at all the more crowded O-TBDPS bond.

The next step was the oxidation of the hydroxy group of $\mathbf{3 3}$ to the corresponding carboxylic acid, a step that Lee et al. described as painfully difficult in his report of the total synthesis of amphidinolide ${ }^{4}{ }^{4}$ where oxidation with DMP of a substrate very similar to 33 (with O-TIPS at C18 instead of O-TBDPS) caused scrambling of the NMR signals of the side-chain region; however, they accomplished the oxidation of this alcohol to the corresponding aldehyde with 2-iodoxybenzoic acid (IBX), also used by Mohapatra $^{6 e}$ in a simpler molecule lacking the side-chain diene. In our hands, all attempts at oxidation with IBX of a similar substrate (with O-TES at C18 instead of O-TBDPS) affected the internal diene NMR signals. This forced us to reevaluate the oxidation of this sensitive molecule, using DMP (stored under vacuum in a desiccator over KOH pellets) in the presence of 2,6lutidine or $\mathrm{NaHCO}_{3}$, because we suspected that the acidic medium-2 mol of AcOH are obviously generated per mol of DMPand/or the reagent impurities initiated the undesired reactions. Our studies with model compounds-intermediates and byproductswere promising. Finally, when we treated 33 with DMP and $\mathrm{NaHCO}_{3}$ (finely powdered and dried over $\mathrm{P}_{4} \mathrm{O}_{10}$ ), the desired aldehyde was cleanly obtained (Scheme 11), without byproducts arising from the epoxidation of conjugate dienes. This aldehyde was 
immediately oxidized to the corresponding carboxylic acid, 34, in $91 \%$ overall yield; to ensure that the diene moieties were not affected in any way we did not only add an excess of 2-methyl-2-butene but also isoprene as trapping reagents for HOCl.

Cleavage of the TBDPS ether of $\mathbf{3 4}$ was more complicated than expected. This is probably due to the steric hindrance around the protected C18 secondary alcohol, which is surrounded by two secondary stereocenters, and hence it is sterically more crowded than standard secondary alcohols. Using 5 equiv of TBAF at rt the reaction progressed very slowly. After addition of up to 8 equiv of TBAF in several portions to a solution of $\mathbf{3 4}$ in THF at $50{ }^{\circ} \mathrm{C}$ allowed us to obtain sufficient amounts of seco-acid $\mathbf{3 5}$ (Scheme 11), but the conversion was still incomplete. A parallel sequence with the TBS analog of $\mathbf{3 4}$ (also prepared from $\mathbf{2 8}$ successfully) gave only rise to slightly better deprotection percentages. In principle, the separation of $\mathbf{3 4}$ and $\mathbf{3 5}$ by chromatography, followed by subjecting again the recovered starting material, $\mathbf{3 4}$, to the deprotection reaction, should solve the issue, but the protecting groups of the polar hydroxy acid $\mathbf{3 5}$ proved to be sensitive to silica gel and/or the eluents, with formation of byproducts during each attempted purification.

\section{Scheme 11. Preparation of seco-Acid 35}

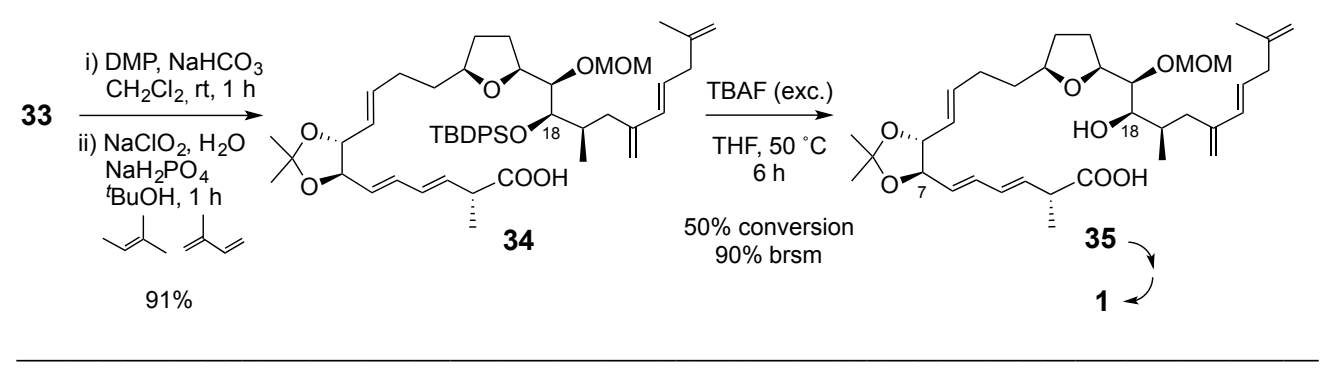

Compound 35 showed the expected HRMS(ESI-) and their NMR spectra agreed with those reported. ${ }^{4}$ Copies of these spectra are included in the Supporting Information section. This constitutes a formal total synthesis of amphidinolide E (1), since $\mathbf{3 5}$ had been converted into 1 in $44 \%$ yield by Lee et al. ${ }^{4}$ by means of the Kita-Trost macrolactonization, ${ }^{24 b}$ followed by the removal of the protecting groups.

The macrolactonization should not be carried out in the presence of DMAP (e.g., by the Shiina method), ${ }^{24 a}$ due to the partial epimerization that can occur at $\mathrm{C} 2$ and the probable migration of the double bonds at $\mathrm{C} 3$ and $\mathrm{C} 5$. Thus, it was wise to rely also upon the Kita-Trost procedure, which uses $\mathrm{HC} \equiv \mathrm{C}-\mathrm{OEt}$ and a Lewis acid, $\left[\mathrm{RuCl}_{2}(p \text {-cymene })\right]_{2}$, for the activation of the carboxyl group, and a Brönsted acid (CSA) for the cyclization. As mentioned in the preceding paragraph, this approach had been already tested. ${ }^{4}$ In our hands, according to the ${ }^{1} \mathrm{H}$ NMR spectrum and HRMS of the crude product, the macrocyclization did partially work in variable yields (20-40\% in different attempts with few mg of 35) but was accompanied by open byproducts, such as the 17,18-dihydroxy acid and the 17,18-O-methylene carboxylic acid lacking the 7,8-O-isopropylidene acetal, which means an 
unfortunate loss of valuable material in the penultimate step of a challenging total synthesis. Our plans for the future involve the improvement of the troublesome antepenultimate and penultimate steps of this total synthesis - the cleavage of a crowded silyl ether and the macrolactonization of a substrate that is especially sensitive to bases and acids, respectively—, which may include a change of tactics (PGs) and/or the recovery of open byproducts and their cyclization. We need a few mg of $\mathbf{1}$ (and of their derivatives and stereoisomers) for the determination of the mechanism of action of this cytotoxic natural product, as we did with other amphidinolides. ${ }^{2 b, d}$

\section{CONCLUSIONS}

The synthetic challenges inherent to the two conjugate dienes of amphidinolide E (1) and its C2 stereocenter (allylic and $\alpha$ to the carboxy group) have been overcome by means of three Julia-Kocienski olefinations and a Suzuki-Molander reaction. In fact, the synthesis of $\mathbf{1}$ has turned out to be the most demanding among those the senior author has been engaged in the past twenty years. In our opinion, this adds more value to the total syntheses accomplished by the groups of Lee and Roush years ago. Our strategy, designed independently years ago as well, has no special advantages with regard to the number of steps (our longest linear sequence involves 25 steps to seco-acid 35) and overall yield (ca. 7\%), but during this long journey we have gained insight into and improved several venerable reactions. The antepenultimate step (the cleavage of the sterically crowded O-Si bond located at C18) and the penultimate step (a CSA-mediated macrolactonization, which also involves the $\mathrm{OH}$ at $\mathrm{C} 18$ ) are problematic and would require further efforts before scaling up the process.

As known, the $\mathrm{J}-\mathrm{K}$ reaction is an outstanding method for the stereoselective formation of double bonds, but sometimes, with polyfunctional substrates such as those dealt with here, gives rise to unpredictable outcomes (often quite poor). ${ }^{22}$ Moreover, to complete the reaction, a relative excess of one or another reactant must be added, which introduces further complications (including a higher probability of self-condensations of heteroaryl sulfones and/or aldol reactions). Because of the dependence of yield and selectivity on the features of each sulfone and aldehyde to be coupled, a general procedure cannot be recommended but, by optimizing the reaction conditions in each case, we have disclosed technical details and tricks that may be useful in other cases:

(i) We have confirmed the tendency of potassium salts of $\mathrm{PT}-\mathrm{SO}_{2} \mathrm{CH}_{2} \mathrm{R}$ to chiefly afford double bonds of $E$ configuration, when the main solvent is DMF. We also confirmed that addition of 18 -crown-6 may be advantageous, ${ }^{15}$ regarding yields and $E / Z$ ratios. This was the case for the formation of the C5-C6 double bond in Scheme 4 (allylic sulfone vs. $\alpha$-alkoxy aldehyde) and for the formation of the C9-C10 double bond in Scheme 10 (multifunctional sulfone vs. multifunctional $\alpha$-alkoxy aldehyde), but it was not necessary for the formation of the C17-C18 double bond (Table 1, simpler substrates).

(ii) Allylic sulfones can be prepared in excellent yields, with only small amounts of byproducts arising from the rearrangement of the intermediate allylic sulfoxides, under the conditions of Scheme 3, while the partial $E$-to- $Z$ isomerizations of the allyl sulfone moiety during the $\mathrm{J}-\mathrm{K}$ reaction course can be reduced at minimum under the conditions of Scheme 4. 
(iii) If the metallic salt of anion $\mathrm{PT}-\mathrm{SO}_{2} \mathrm{CH} \mathrm{R}$ is stable under the reaction conditions, that is, if the sulfone can be recovered unchanged after the reaction and final neutralization — a fact that can be easily proved by a blank experiment with very few mg of the substrate-, it is better to use a large molar excess of $\mathrm{PT}-\mathrm{SO}_{2} \mathrm{CH}^{-} \mathrm{R} / \mathrm{PT}-\mathrm{SO}_{2} \mathrm{CH}_{2} \mathrm{R}$ with regard to the aldehyde (often chiral, usually enolizable in the presence of a strong base), as we did in the complex case of Scheme 10.

\section{EXPERIMENTAL SECTION}

General Methods. Unless specified otherwise, all starting materials and reagents were obtained from commercial suppliers and used without further purification. All reactions were conducted in oven-dried glassware, under $\mathrm{N}_{2}$ or $\mathrm{Ar}$, with anhydrous solvents, which were dried and distilled before use according to standard procedures. Solvents used for isolation of products and chromatography were glass distilled. Analytical thin-layer chromatography (TLC) was performed on $0.25 \mathrm{~mm}$ silica gel plates $\left(\mathrm{F}_{254}\right)$; retention factors $\left(R_{f}\right)$ are approximate. Flash column chromatography was performed on silica gel $(35-70 \mu \mathrm{m})$. Yields were determined after purification of the desired compound by flash column chromatography on silica gel and removal of last traces of solvent (high vacuum, up to constant weight). IR spectra were recorded using an attenuated total reflectance FTIR apparatus and the wavenumbers of maximum absorption peaks are reported in $\mathrm{cm}^{-1} .{ }^{1} \mathrm{H}$ NMR spectra were recorded on $400 \mathrm{MHz}$ spectrometers; chemical shifts are reported in ppm ( $\delta$ values), in $\mathrm{CDCl}_{3}$, with TMS as internal reference or with the solvent resonance as the internal standard $\left(\mathrm{CHCl}_{3}\right.$ impurity in $\left.\mathrm{CDCl}_{3}, \delta 7.26 \mathrm{ppm}\right)$; data are reported in the following order: chemical shift, multiplicity $(\mathrm{s}=$ singlet, $\mathrm{d}=$ doublet, $\mathrm{t}=$ triplet, $\mathrm{q}=$ quartet, quint $=$ quintuplet, $\mathrm{br}=$ broad, $\mathrm{m}=$ multiplet $)$, coupling constants in $\mathrm{Hz}$, integration. ${ }^{13} \mathrm{C}$ NMR spectra were recorded in $\mathrm{CDCl}_{3}$ on the above-mentioned spectrometers $\left(100.6 \mathrm{MHz}\right.$ for $\left.{ }^{13} \mathrm{C}\right)$ with complete proton decoupling (BB) and DEPT; chemical shifts are reported in ppm ( $\delta$ values) with the solvent as the internal standard $\left(\mathrm{CDCl}_{3}, \delta 77.0 \mathrm{ppm}\right)$. Where necessary, 2D NMR experiments (HSQC and NOESY) were carried out to assist in structure elucidation and signal assignments. Optical rotations were measured on a polarimeter at $20{ }^{\circ} \mathrm{C}$ and are reported as follows: $[\alpha]_{\mathrm{D}}(c$ in $\mathrm{g} / 100 \mathrm{~mL}$, solvent). The high-resolution mass spectra (HRMS, $m / z$ values) were obtained by the electrospray ionization (ESI, TOF) technique, in the positive or negative mode (as indicated).

$(4 R, 5 R)$-2,2-Dimethyl-5-(triethylsilyloxymethyl)-1,3-dioxolan-4-yl)methanol, $(2 R, 3 R)$-2,3-O-isopropylidene-4-(triethylsilyloxy)-1,2,3butanetriol (3). Sodium hydride $(\mathrm{NaH}, 60 \%$ dispersion in mineral oil, $492 \mathrm{mg}, 0.012 \mathrm{~mol})$ was added to a solution of $(2 R, 3 R)-2,3-O-$ isopropylidenebutane-1,4-diol $(1.90 \mathrm{~g}, 0.010 \mathrm{~mol})$ in anhydrous THF $(58 \mathrm{~mL})$ at $0{ }^{\circ} \mathrm{C}$. Triethylsilyl chloride (TESCl, $\left.20 \mathrm{~mL}, 0.010 \mathrm{mmol}\right)$ was then added and the reaction mixture was stirred at $\mathrm{rt}$ for $3 \mathrm{~h}$, poured into water $(150 \mathrm{~mL})$ and extracted with $\mathrm{CH}_{2} \mathrm{Cl}_{2}(2 \times 100 \mathrm{~mL})$. The combined organic layers were washed with brine $(50 \mathrm{~mL})$, dried over $\mathrm{Na}_{2} \mathrm{SO}_{4}$, and concentrated under high pressure. Purification by flash column chromatography (hexanes/EtOAc, 6:4) afforded 3 (2.23 g, 70\%) as a colorless oil: $\mathrm{R}_{f}$ (hexanes/EtOAc, 7:3) 0.3; $[\alpha]_{\mathrm{D}}-15.6\left(c\right.$ 2.07, $\left.\mathrm{CHCl}_{3}\right)$; IR 3465, 2912, 1239, 1079, 1003; ${ }^{1} \mathrm{H}$ NMR 0.62 (q, $\left.J=7.9,6 \mathrm{H}\right), 0.96$ (t, $\left.J=8.0,9 \mathrm{H}\right), 1.40$ (s, 3H), 1.41 (s, 3H), $3.65(\mathrm{~m}, 1 \mathrm{H}), 3.70-3.78$ (m, 2H), 3.85-3.91 (m, $\left.2 \mathrm{H}\right), 3.97$ (dt, $J=$ 7.6, 4.7, $1 \mathrm{H}) ;{ }^{13} \mathrm{C}$ NMR 4.1, 6.5, 26.8, 26.9, 62.7, 63.3, 78.3, 80.1, 109.0; HRMS (ESI+) calcd for $\mathrm{C}_{13} \mathrm{H}_{29} \mathrm{O}_{4} \mathrm{Si}(\mathrm{M}+\mathrm{H}){ }^{+} 277.1830$, found 277.1827 .

(2S,3R)-2,3-O-Isopropylidene-4-(triethylsilyloxy)butanal (4). Sodium hydrogen carbonate $\left(\mathrm{NaHCO}_{3}, 1.60 \mathrm{~g}, 19.0 \mathrm{mmol}\right)$ and Dess-Martin periodinane (DMP, $860 \mathrm{mg}, 2.02 \mathrm{mmol})$ were added to a solution of 3 (525 mg, $1.89 \mathrm{mmol})$ in $\mathrm{CH}_{2} \mathrm{Cl}_{2}(19 \mathrm{~mL})$. The reaction mixture was stirred for $1 \mathrm{~h}$ at $0{ }^{\circ} \mathrm{C}$ and at $\mathrm{rt}$ for $30 \mathrm{~min}$ and was then quenched with a saturated aqueous solution of $\mathrm{Na}_{2} \mathrm{~S}_{2} \mathrm{O}_{3}(100 \mathrm{~mL})$ and diluted with Et $2 \mathrm{O}(100 \mathrm{~mL})$. 
The layers were separated, the aqueous layer was extracted with $\mathrm{Et}_{2} \mathrm{O}(3 \times 70 \mathrm{~mL})$, and the combined organic extracts were dried over $\mathrm{MgSO}_{4}$ and concentrated. The residue was purified on silica gel (hexanes/EtOAc, 7:3) to give $500 \mathrm{mg}(90 \%)$ of 4 as a colorless oil: $\mathrm{R}_{f}($ hexanes/EtOAc, $8: 2) 0.45$; $[\alpha]_{\mathrm{D}}-$ 4.1 (c 1.56, $\left.\mathrm{CHCl}_{3}\right)$; IR 2953, 2912, 2876, 1735, 1456, 1239, 1077; ${ }^{1} \mathrm{H}$ NMR 0.62 (q, $\left.J=8.0,6 \mathrm{H}\right), 0.96(\mathrm{t}, J=7.9,9 \mathrm{H}), 1.42(\mathrm{~s}, 3 \mathrm{H}), 1.48(\mathrm{~s}, 3 \mathrm{H}), 3.80(\mathrm{~m}$, 2H, AB part of an ABX system), $4.12(\mathrm{dt}, J=7.3,4.6,1 \mathrm{H}), 4.31(\mathrm{dd}, J=7.3,1.6,1 \mathrm{H}), 9.77(\mathrm{~d}, J=1.6,1 \mathrm{H}) ;{ }^{13} \mathrm{C} \mathrm{NMR} 4.5,6.8,26.3,26.6,62.8,77.6,82.0$, 111.5, 200.7; HRMS (ESI+) calcd for $\mathrm{C}_{13} \mathrm{H}_{27} \mathrm{O}_{4} \mathrm{Si}(\mathrm{M}+\mathrm{H})^{+}$275.1673, found 275.1677 .

(S)-4-Benzyl-3-\{(2R,3E)-2-methyl-5-[(1-phenyl-1H-tetrazol-5-yl)thio]-3-pentenoyl\}-1,3-oxazolidin-2-one (6). Triphenylphosphine (3.30 g, $12.0 \mathrm{mmol})$ and 1-phenyl-1H-tetrazole-5-thiol $(2.22 \mathrm{~g}, 12.0 \mathrm{mmol})$ were added to a solution of alcohol $5^{6 \mathrm{c}}(2.40 \mathrm{~g}, 8.0 \mathrm{mmol}) \mathrm{in} \mathrm{THF}(80 \mathrm{~mL})$. The mixture was cooled to $0{ }^{\circ} \mathrm{C}$ and diethyl azodicarboxylate (DEAD, $40 \%$ in toluene, $6.6 \mathrm{~mL}, 14.0 \mathrm{mmol}$ ) was added. The solution was stirred for $1 \mathrm{~h}$ at $\mathrm{rt}$ and was then quenched by addition of a saturated aqueous solution of $\mathrm{NaHCO}_{3}(150 \mathrm{~mL})$. The aqueous phase was extracted with $\mathrm{CH}_{2} \mathrm{Cl}_{2}(3$ $\times 75 \mathrm{~mL}$ ), and the combined organic extracts were washed with brine $(150 \mathrm{~mL})$, dried over $\mathrm{MgSO}_{4}$, filtered, and concentrated under reduced pressure. The residue was purified by flash column chromatography (hexanes/EtOAc, 6:4) to yield $3.40 \mathrm{~g}$ (91\%) of 6 as a colorless oil: $\mathrm{R}_{f}$ (hexanes/EtOAc, 6:4) 0.55; $[\alpha]_{\mathrm{D}}+18.5\left(c 0.49, \mathrm{CHCl}_{3}\right) ;{ }^{1} \mathrm{H}$ NMR $1.27(\mathrm{~d}, J=6.9,3 \mathrm{H}), 2.74(\mathrm{dd}, J=13.4,9.7), 3.24(\mathrm{dd}, J=13.4,3.3), 4.01-4.14$ $(\mathrm{m}, 2 \mathrm{H}), 4.14-4.22(\mathrm{~m}, 2 \mathrm{H}), 4.44$ (quint, $J=7.0,1 \mathrm{H}), 4.66(\mathrm{ddd}, J=13.2,7.2,3.5,1 \mathrm{H}), 5.84(\mathrm{dd}, J=15.3,7.2,1 \mathrm{H}), 6.00(\mathrm{dd}, J=15.3,7.7,1 \mathrm{H})$, 7.17-7.21 (m, 2H), 7.27-7.35 (m, 3H), 7.52-7.58 (m, 5H); ${ }^{13} \mathrm{C}$ NMR 16.9, 35.2, 37.7, 40.5, 55.2, 66.1, 123.5, 125.6, 127.3, 128.9, 129.4, 129.8, 130.1, 130.2, 134.6, 135.2, 152.9, 153.6, 174.1; HRMS (ESI+) calcd for $\mathrm{C}_{23} \mathrm{H}_{24} \mathrm{~N}_{5} \mathrm{O}_{3} \mathrm{~S}^{+}(\mathrm{M}+\mathrm{H})^{+} 450.1594$, found 450.1600 .

(2R,3E)-2-Methyl-5-[(1-phenyl-1H-tetrazol-5-yl)thio]-3-penten-1-ol (7). Sodium tetrahydridoborate (sodium borohydride, $\mathrm{NaBH}_{4}, 67$ $\mathrm{mg}, 1.7 \mathrm{mmol})$ was added in portions for $1 \mathrm{~h}$ to a stirring solution of $6(619 \mathrm{mg}, 1.30 \mathrm{mmol})$ in $1: 1 \mathrm{THF}-$ water $(14 \mathrm{~mL})$ at $0{ }^{\circ} \mathrm{C}$. The reaction mixture was stirred at $\mathrm{rt}$ for $2 \mathrm{~h}$ and was then quenched with a $2 \mathrm{M} \mathrm{HCl}$ solution $(20 \mathrm{~mL})$ and diluted with $\mathrm{CH}_{2} \mathrm{Cl}_{2}(20 \mathrm{~mL})$. The phases were separated and the aqueous layer was extracted with $\mathrm{CH}_{2} \mathrm{Cl}_{2}(3 \times 20 \mathrm{~mL})$. The combined organic layers were washed with brine $(20 \mathrm{~mL})$ and dried over $\mathrm{MgSO}_{4}$. After filtration and evaporation of the solvent, the residue was purified on silica gel (hexanes/EtOAc, 1:1) to give $330 \mathrm{mg}$ $(89 \%)$ of 7 as a colorless oil: $\mathrm{R}_{f}$ (hexanes/EtOAc, 7:3) $\left.0.3 ; \alpha\right]_{\mathrm{D}}+22.1\left(c 8.19, \mathrm{CHCl}_{3}\right) ;{ }^{1} \mathrm{H}$ NMR $0.97(\mathrm{~d}, J=6.8,3 \mathrm{H}), 1.82(\mathrm{br} \mathrm{s}, 1 \mathrm{H}) 2.30-2.42$ (m, 1H), $3.41(\mathrm{dd}, J=10.6,7.4,1 \mathrm{H}), 3.49(\mathrm{dd}, J=10.6,5.6,1 \mathrm{H}), 3.96(\mathrm{~m}, 2 \mathrm{H}), 5.64-5.76(\mathrm{~m}, 2 \mathrm{H}), 7.55(\mathrm{~m}, 5 \mathrm{H}) ;{ }^{13} \mathrm{C} \mathrm{NMR} 16.0,35.6,39.4$ 67.0, 123.9, 124.1, 129.8, 130.1, 133.6, 139.1, 153.8; HRMS (ESI+) calcd for $\mathrm{C}_{13} \mathrm{H}_{17} \mathrm{~N}_{4} \mathrm{OS}^{+}(\mathrm{M}+\mathrm{H})^{+} 277.1118$, found 277.1124 .

(2E,4R)-5-(tert-Butyldiphenylsilyloxy)-4-methyl-1-[(1-phenyl-1H-tetrazol-5-yl)thio]-2-pentene (8). tert-Butyldiphenylsilyl chloride (TBDPSCl, $423 \mu \mathrm{L}, 447 \mathrm{mg}, 1.62 \mathrm{mmol})$ was added dropwise to a stirring solution of alcohol 7 (300 mg, $1.08 \mathrm{mmol})$ and imidazole (1.49 g, $2.17 \mathrm{mmol})$ in THF $(5.4 \mathrm{~mL})$ at $0{ }^{\circ} \mathrm{C}$. After $1 \mathrm{~h}$ at $\mathrm{rt}$ the reaction was quenched with water $(50 \mathrm{~mL})$ and diluted with $\mathrm{CH}_{2} \mathrm{Cl}_{2}(30 \mathrm{~mL})$. The phases were separated and the aqueous layer was extracted with $\mathrm{CH}_{2} \mathrm{Cl}_{2}(3 \times 30 \mathrm{~mL})$. The combined organic extracts were dried over $\mathrm{MgSO}_{4}$, filtered, and concentrated. The residue was purified on silica gel (hexanes/EtOAc, 8:2) to give $489 \mathrm{mg}(96 \%)$ of 8 as a white solid: $\mathrm{mp} 46-48{ }^{\circ} \mathrm{C}$. $\mathrm{R}_{f}($ hexanes/EtOAc, $8: 2$ ) 0.55; $[\alpha]_{\mathrm{D}}+2.5\left(c\right.$ 0.92, $\left.\mathrm{CHCl}_{3}\right) ;$ IR 3072, 2955, 2921, 2857, 1606, 1499, 1385, 1110; ${ }^{1} \mathrm{H}$ NMR $0.99(\mathrm{~d}, J=6.8,3 \mathrm{H}), 1.03(\mathrm{~s}, 9 \mathrm{H}), 2.33-2.45(\mathrm{~m}$, $1 \mathrm{H}), 3.49-3.53(\mathrm{~m}, 2 \mathrm{H}), 4.01(\mathrm{~d}, J=7.1,2 \mathrm{H}), 5.66(\mathrm{dtd}, J=15.2,7.1,0.8,1 \mathrm{H}), 5.78(\mathrm{dd}, J=15.4,7.1,1 \mathrm{H}), 7.33-7.44(\mathrm{~m}, 6 \mathrm{H}), 7.51-7.58(\mathrm{~m}, 5 \mathrm{H})$, 7.62-7.66 (m, 4H); ${ }^{13} \mathrm{C}$ NMR 16.2, 19.3, 26.8, 35.7, 39.1, 68.1, 122.6, 123.7, 127.6, 129.5, 129.7, 130.0, 133.7, 135.6, 139.6, 154.0; HRMS (ESI+) calcd for $\mathrm{C}_{29} \mathrm{H}_{35} \mathrm{~N}_{4} \mathrm{OSSi}^{+}(\mathrm{M}+\mathrm{H})^{+}$515.2295, found 515.2308. 
(2E,4R)-5-(tert-Butyldiphenylsilyloxy)-4-methyl-1-[(1-phenyl-1H-tetrazol-5-yl)sulfonyl]-2-pentene (9). A solution of ammonium heptamolybdate - tetrahydrate $(687 \mathrm{mg}, 0.55 \mathrm{mmol})$ in $33 \% \mathrm{w} / \mathrm{w} \mathrm{H}_{2} \mathrm{O}_{2}(7.9 \mathrm{~mL})$ was added to a stirring solution of 8 (714 mg, $\left.1.39 \mathrm{mmol}\right)$ in EtOH $(27.6 \mathrm{~mL})$ at $0{ }^{\circ} \mathrm{C}$. After $3 \mathrm{~h}$ at $\mathrm{rt}$ the reaction was quenched with a saturated aqueous $\mathrm{NH}_{4} \mathrm{Cl}$ solution $(80 \mathrm{~mL})$ and $\mathrm{CH}_{2} \mathrm{Cl}_{2}(50 \mathrm{~mL})$. The aqueous layer was extracted with $\mathrm{CH}_{2} \mathrm{Cl}_{2}(2 \times 50 \mathrm{~mL})$ and the combined organic fractions were dried over anhydrous $\mathrm{Na}_{2} \mathrm{SO}_{4}$, filtered, and concentrated. Flash column chromatography (hexanes/EtOAc, 9:1) provided $666 \mathrm{mg}(88 \%)$ of 9 as a colorless oil: $\mathrm{R}_{f}\left(\right.$ hexanes/EtOAc, 8:2) 0.6; $[\alpha]_{\mathrm{D}}+9.6(c 1.36$, $\mathrm{CHCl}_{3}$ ); IR 3070, 2930, 1471, 1345, 1112; ${ }^{1} \mathrm{H}$ NMR 0.98 (d, $\left.J=6.8,3 \mathrm{H}\right), 1.03$ (s, 9H), 2.36-2.47 (m, 1H), $3.50(\mathrm{~d}, J=6.3,2 \mathrm{H}), 4.35$ (d, $J=7.4$, $2 \mathrm{H}), 5.52(\mathrm{dt}, J=15.6,7.4,1 \mathrm{H}), 5.93$ (dd, $J=15.5,7.2,1 \mathrm{H}), 7.34-7.45$ (m, 8H), 7.54-7.66 (m, 7H, Ph); ${ }^{13} \mathrm{C}$ NMR 16.0, 19.3, 26.8, 39.6, 59.9, 67.8, 112.7, 125.2, 127.7, 129.7, 131.4, 133.0, 133.6, 134.8, 135.6, 147.4, 153.2; HRMS (ESI+) calcd for $\mathrm{C}_{29} \mathrm{H}_{34} \mathrm{~N}_{4} \mathrm{NaO}_{3} \mathrm{SSi}^{+}(\mathrm{M}+\mathrm{Na})^{+} 569.2013$, found 569.2000

$(2 R, 3 E, 5 E, 7 R, 8 R)$-1-tert-Butyldiphenylsilyloxy-7,8-O-isopropylidene-2-methyl-9-(triethylsilyloxy)-3,5-nonadiene, (3E,5E)-10. A solution of KHMDS (66 mg, $0.33 \mathrm{mmol})$ and 18-crown-6 $(88 \mathrm{mg}, 0.33 \mathrm{mmol})$ in dry DMF $(0.7 \mathrm{~mL})$ was added dropwise to a stirred solution of sulfone $9(73 \mathrm{mg}, 0.13 \mathrm{mmol})$ and aldehyde $4(50 \mathrm{mg}, 0.16 \mathrm{mmol})$ in anhydrous DMF $(0.6 \mathrm{~mL})$ at $-65^{\circ} \mathrm{C}$ under Ar. After the addition, the temperature was raised to $-40{ }^{\circ} \mathrm{C}$ and stirring was continued for $6 \mathrm{~h}$. The reaction was quenched with a saturated $\mathrm{NH}_{4} \mathrm{Cl}$ solution $(20 \mathrm{~mL})$ and diluted with EtOAc $(10 \mathrm{~mL})$. The aqueous phase was extracted with EtOAc $(3 \times 10 \mathrm{~mL})$ and the organic phases were combined and washed with brine $(30$ $\mathrm{mL}$ ), dried over $\mathrm{Na}_{2} \mathrm{SO}_{4}$, filtered, and concentrated under reduced pressure. The residue was purified by flash column chromatography (hexanes/EtOAc, 9:1) to afford $63 \mathrm{mg}(80 \%)$ of a 82:13:5 mixture of (3E,5E)-10, $(3 E, 5 Z)-\mathbf{1 0}$, and (3Z,5E)-10. A sample of pure (3E,5E)-10 was isolated after a second flash chromatography: colorless oil; $\mathrm{R}_{f}$ (hexanes/EtOAc, 9:1) 0.7; $[\alpha]_{\mathrm{D}}+8.4\left(c 0.89, \mathrm{CHCl}_{3}\right) ; \mathrm{IR} 1955,2930,2875,1460$, 1427, 1251, 1116, 1087; ${ }^{1} \mathrm{H}$ NMR $0.61(\mathrm{q}, J=7.9,6 \mathrm{H}), 0.95(\mathrm{t}, J=7.9,9 \mathrm{H}), 1.05(\mathrm{~s}, 12 \mathrm{H}), 1.41(\mathrm{~s}, 3 \mathrm{H}), 1.43(\mathrm{~s}, 3 \mathrm{H}), 2.49-2.36(\mathrm{~m}, 1 \mathrm{H}), 3.49$ (dd, $J=9.7,6.6,1 \mathrm{H}), 3.54(\mathrm{dd}, J=9.7,6.4,1 \mathrm{H}), 3.63-3.82(\mathrm{~m}, 3 \mathrm{H}), 4.33(\mathrm{t}, J=7.5,1 \mathrm{H}), 5.56(\mathrm{dd}, J=15.2,7.4,1 \mathrm{H}), 5.66(\mathrm{dd}, J=15.3,7.3$, $1 \mathrm{H}), 6.05(\mathrm{dd}, J=15.3,10.5,1 \mathrm{H}), 6.26(\mathrm{dd}, J=15.2,10.4,1 \mathrm{H}), 7.33-7.45(\mathrm{~m}, 5 \mathrm{H}), 7.63-7.67(\mathrm{~m}, 5 \mathrm{H}) ;{ }^{13} \mathrm{C}$ NMR 4.4, 6.7, 16.4, 19.3, 26.8, 26.9, 27.1, 39.3, 62.3, 68.4, 78.7, 81.6, 109.0, 127.6, 127.0, 128.9, 129.5, 133.9, 134.1, 135.6, 138.4; HRMS (ESI+) calcd for $\mathrm{C}_{35} \mathrm{H}_{58} \mathrm{NO}_{4} \mathrm{Si}_{2}{ }^{+}$ $\left(\mathrm{M}+\mathrm{NH}_{4}\right)^{+} 612.3899$, found 612.3905 .

Selective deprotection of 10. Pyridinium $p$-toluenesulfonate (PPTS, $98 \mathrm{mg}, 0.39 \mathrm{mmol}$ ) was added to a mixture of diastereoisomers $(\mathbf{1 0}, 289$ $\mathrm{mg}, 0.49 \mathrm{mmol})$ in $\mathrm{CH}_{2} \mathrm{Cl}_{2}(20 \mathrm{~mL})$ and $\mathrm{EtOH}(3.3 \mathrm{~mL})$ at $0{ }^{\circ} \mathrm{C}$. The reaction was stirred overnight at rt. Triethylamine $\left(\mathrm{Et}_{3} \mathrm{~N}, 0.1 \mathrm{~mL}\right)$ was then added and the solvent was removed under reduced pressure. A flash column chromatography on silica gel (hexanes/EtOAc, 8:2) allowed us to isolate (3E,5E)-11 (174 mg, 75\%, ca. 65\% overall yield) and (3E,5Z)-11 (50 mg, 21\%, ca. 10\% overall yield). Data for ( $2 R, 3 R, 4 E, 6 E, 7 R)-9$-tertbutyldiphenylsilyloxy-2,3- $O$-isopropylidene-8-methyl-4,6-nonadien-1-ol, $(3 E, 5 E)$-11: colorless oil; $\mathrm{R}_{f}\left(\right.$ hexanes/EtOAc, 9:1) $0.20 ;[\alpha]_{D}+3.4(c$ $\left.1.15, \mathrm{CHCl}_{3}\right)\left[\mathrm{lit}^{4 \mathrm{aa}}[\alpha]_{\mathrm{D}}^{26}+4.4\left(c 0.55, \mathrm{CHCl}_{3}\right) ;\right.$ lit. $\left.^{6 \mathrm{e}}[\alpha]_{\mathrm{D}}:+6.4\left(c 3.9, \mathrm{CHCl}_{3}\right)\right] ;$ IR $2955,2874,1590,1456,1427,1250,1080 ;{ }^{1} \mathrm{H} \mathrm{NMR} 1.03(\mathrm{~d}, J$ $=6.8,3 \mathrm{H}), 1.04(\mathrm{~s}, 9 \mathrm{H}), 1.44(\mathrm{~s}, 3 \mathrm{H}), 1.44(\mathrm{~s}, 3 \mathrm{H}), 2.39-2.48(\mathrm{~m}, 1 \mathrm{H}), 3.47-3.55(\mathrm{~m}, 2 \mathrm{H}), 3.56-3.62(\mathrm{~m}, 1 \mathrm{H}), 3.75-3.80(\mathrm{~m}, 1 \mathrm{H}), 3.80-3.86(\mathrm{~m}$, $1 \mathrm{H}), 4.35(\mathrm{t}, J=8.0,1 \mathrm{H}), 5.53(\mathrm{dd}, J=15.2,7.9,1 \mathrm{H}), 5.68(\mathrm{dd}, J=15.3,7.3,1 \mathrm{H}), 6.05(\mathrm{dd}, J=15.3,10.4,1 \mathrm{H}), 6.28(\mathrm{dd}, J=15.2,10.4,1 \mathrm{H}), 7.34$ 7.44 (m, 6H), 7.63-7.67 (m, 4H); ${ }^{13} \mathrm{C}$ NMR 16.3, 19.3, 26.8, 26.9, 27.1, 39.3, 60.7, 68.3, 77.8, 81.1, 109.0, 127.0, 127.4, 128.7, 129.5, 133.8, 135.0, 135.6, 139.0; HRMS (ESI+) calcd for $\mathrm{C}_{29} \mathrm{H}_{44} \mathrm{NO}_{4} \mathrm{Si}^{+}\left(\mathrm{M}+\mathrm{NH}_{4}\right)^{+}$498.3034, found 498.3032. NMR data are consistent with previously reported values. ${ }^{4 a, 6 e}$ Data for $(2 R, 3 R, 4 Z, 6 E, 7 R)$-9-tert-butyldiphenylsilyloxy-2,3-O-isopropylidene-8-methylnona-4,6-dien-1-ol, (3E,5Z)-11: colorless oil; 
$\mathrm{R}_{f}$ (hexanes/EtOAc, 9:1) 0.25; $[\alpha]_{\mathrm{D}}+12.1\left(\mathrm{c} \mathrm{4.19}, \mathrm{CHCl}_{3}\right) ;{ }^{1} \mathrm{H}$ NMR $1.05(\mathrm{~s}, 12 \mathrm{H}), 1.46(\mathrm{~s}, 6 \mathrm{H}), 2.42-2.53(\mathrm{~m}, 1 \mathrm{H}), 3.48-3.59(\mathrm{~m}, 3 \mathrm{H}), 3.72-3.77$ (m, 1H), $3.82(\mathrm{dd}, J=12.1,2.8,1 \mathrm{H}), 4.85(\mathrm{t}, J=8.7,1 \mathrm{H}), 5.27-5.35(\mathrm{~m}, 1 \mathrm{H}), 5.73(\mathrm{dd}, J=15.0,7.4,1 \mathrm{H}), 6.18(\mathrm{t}, J=11.0,1 \mathrm{H}), 6.35(\mathrm{dd}, J=15.0$, 11.1, 1H), 7.32-7.46 (m, 6H), 7.62-7.68 (m, 4H); ${ }^{13} \mathrm{C}$ NMR 16.4, 19.3, 26.9, 27.0, 27.0, 39.5, 60.4, 68.4, 72.9, 81.4, 109.1, 124.4, 124.8, 127.6, 129.5, 133.9, 134.1, 135.6, 140.9; HRMS (ESI+) calcd for $\mathrm{C}_{29} \mathrm{H}_{44} \mathrm{NO}_{4} \mathrm{Si}^{+}\left(\mathrm{M}+\mathrm{NH}_{4}\right)^{+} 498.3034$, found 498.3037 .

(2S,3R,4E,6E,7R)-9-tert-Butyldiphenylsilyloxy-8-methyl-2,3-O-(1,1-dimethylmethylene)-4,6-nonadien-1-al (12). To a solution of (3E,5E)11 (48 mg, $0.10 \mathrm{mmol})$ in $\mathrm{CH}_{2} \mathrm{Cl}_{2}(1 \mathrm{~mL})$ was added $\mathrm{NaHCO}_{3}(8 \mathrm{mg}, 0.1 \mathrm{mmol})$ and DMP $(55 \mathrm{mg}, 0.12 \mathrm{mmol})$ under $\mathrm{N}_{2}$ at rt. After stirring for $1 \mathrm{~h}$, the mixture was quenched with a saturated aqueous solution of $\mathrm{Na}_{2} \mathrm{~S}_{2} \mathrm{O}_{3}(10 \mathrm{~mL})$ and diluted with $\mathrm{Et}_{2} \mathrm{O}(10 \mathrm{~mL})$, and the aqueous layer was extracted with $\mathrm{Et}_{2} \mathrm{O}(3 \times 10 \mathrm{~mL})$. The organic extracts were dried over $\mathrm{MgSO}_{4}$, filtered, and concentrated. The residue was purified on silica gel (hexanes/EtOAc, 70:30) to give $34 \mathrm{mg}(92 \%)$ of 12 as a yellowish oil: $\mathrm{R}_{f}$ (hexanes/EtOAc, 70:30) 0.60; $[\alpha]_{\mathrm{D}}+11.0\left(c 0.90, \mathrm{CHCl}_{3}\right)\left[{ }^{2}{ }^{4 i t}{ }^{4 a}[\alpha]^{27}{ }_{\mathrm{D}}\right.$ +11.7 (c 0.60, $\left.\mathrm{CHCl}_{3}\right)$ ]; IR 2929, 2856, 1735, 1427, 1214, 1111, 1073; ${ }^{1} \mathrm{H}$ NMR 1.03 (d, $\left.J=6.7,3 \mathrm{H}\right), 1.05$ (s, 9H), 1.46 (s, 3H), 1.50 (s, 3H), $2.38-$ $2.50(\mathrm{~m}, 1 \mathrm{H}), 3.50(\mathrm{dd}, J=9.7,6.5,1 \mathrm{H}), 3.55(\mathrm{dd}, J=9.7,6.3,1 \mathrm{H}), 4.06(\mathrm{dd}, J=7.7,2.1,1 \mathrm{H}), 4.51(\mathrm{t}, J=7.3,1 \mathrm{H}), 5.58(\mathrm{dd}, J=15.2,7.3,1 \mathrm{H})$, $5.71(\mathrm{dd}, J=15.3,7.3,1 \mathrm{H}), 6.05(\mathrm{dd}, J=15.4,10.4,1 \mathrm{H}), 6.29(\mathrm{dd}, J=15.2,10.4,1 \mathrm{H}), 7.34-7.44(\mathrm{~m}, 6 \mathrm{H}), 7.63-7.65(\mathrm{~m}, 4 \mathrm{H}), 9.72(\mathrm{~d}, J=2.1$, $1 \mathrm{H}) ;{ }^{13} \mathrm{C}$ NMR 16.3, 19.3, 26.2, 26.8, 26.9, 39.3, 68.3, 77.8, 84.7, 111.3, 125.8, 127.6, 128.4, 129.6, 133.8, 135.1, 135.6, 139.8, 199.7; HRMS (ESI+) calcd for $\mathrm{C}_{29} \mathrm{H}_{42} \mathrm{NO}_{4} \mathrm{Si}^{+}\left(\mathrm{M}+\mathrm{NH}_{4}\right)^{+} 496.2878$, found 496.2884. NMR data are in agreement with those reported in the literature. ${ }^{4 a}$

(S)-5-tert-Butyldiphenylsilyloxy-1,2-epoxypentane, (S)-2-(3-tert-butyldiphenylsilyloxy)propyloxirane (14). TBDPS-protected 4-penten-1ol [5-(tert-butyldiphenylsilyloxy)-1-pentene], a known compound ${ }^{27}$ (13, $\left.25.0 \mathrm{mg}, 0.077 \mathrm{mmol}\right), \mathrm{CH}_{2} \mathrm{Cl}_{2}(0.4 \mathrm{~mL})$, and $30 \%$ aqueous $\mathrm{H}_{2} \mathrm{O}_{2}$ (without stabilizers) $\left(0.050 \mathrm{~mL}, 0.46 \mathrm{mmol}, 6\right.$ equiv) were added to the Ti-cis-salalen catalyst, prepared independently from $\operatorname{Ti}\left(\mathrm{O}^{\mathrm{i}} \mathrm{Pr}\right)_{4}(6.8 \mu \mathrm{L}$, $0.023 \mathrm{mmol}$ ) and cis-salalen $(11 \mathrm{mg}, 0.023 \mathrm{mmol})$ in anhydrous $\mathrm{CH}_{2} \mathrm{Cl}_{2}$ under Ar, following the protocol described by Berkessel et al. ${ }^{17} \mathrm{~A}$ vigorous stirring was maintained in an open atmosphere, at rt. After 24 h, 6 equiv more of $\mathrm{H}_{2} \mathrm{O}_{2}$ were added. Again, $24 \mathrm{~h}$ later, further 6 equiv of $\mathrm{H}_{2} \mathrm{O}_{2}$ were added, and the vigorous stirring was continued for $24 \mathrm{~h}$ at rt. The reaction mixture was diluted with $\mathrm{CH}_{2} \mathrm{Cl}_{2}(5 \mathrm{~mL})$ and $\mathrm{H}_{2} \mathrm{O}(5$ $\mathrm{mL}$ ), the layers were separated and the aqueous phase was re-extracted with $\mathrm{CH}_{2} \mathrm{Cl}_{2}(5 \mathrm{~mL})$. The combined organic phases were washed with brine $(2 \times 15 \mathrm{~mL})$, dried over $\mathrm{Na}_{2} \mathrm{SO}_{4}$, and filtered. The solvent was removed under reduced pressure and the residue was purified by column chromatography (90:10 hexanes/EtOAc) to afford $14(23.5 \mathrm{mg}, 90 \%)$ as yellowish oil: $\mathrm{R}_{f}$ (hexanes/EtOAc, 80:20) 0.58; $[\alpha]_{\mathrm{D}}-2.4(c \quad 1.0$, $\left.\mathrm{CHCl}_{3}\right)\left[\mathrm{lit}^{28}[\alpha]_{\mathrm{D}}-3.41\left(c 1.12, \mathrm{CHCl}_{3}\right)\right.$, lit. $\left.^{27}[\alpha]_{\mathrm{D}}-2.7\left(c 1.1, \mathrm{CHCl}_{3}\right)\right] ;{ }^{1} \mathrm{H}$ NMR 1.05 (s, 9H), 1.57-1.77 (m, 4H), $2.45(\mathrm{dd}, J=5.0, J=2.7$, 1H), 2.72-2.74 (m, 1H), 2.89-2.93 (m, 1H), 3.66-3.75 (m, 2H), 7.38-7.67 (m, 10H); HPLC (Chiralpack AS-H, hexanes/isopropanol 99.5:0.5, $0.4 \mathrm{~mL} / \mathrm{min}, \lambda=254 \mathrm{~nm}) \mathrm{t}_{\mathrm{R}}(R)=10.7 \mathrm{~min}(\operatorname{minor}), \mathrm{t}_{\mathrm{R}}(S)=11.2 \mathrm{~min}$ (major), 4:96 ratio. NMR data are consistent with reported values. ${ }^{28}$

The reaction was repeated under identical conditions but using the binaphthyl analog of cis-salalen (see Scheme 7). ${ }^{17 \mathrm{c}}$ Only two additions of $0.050 \mathrm{~mL}$ of $30 \% \mathrm{H}_{2} \mathrm{O}_{2}$ (without stabilizers) and two days of reaction were required for the complete epoxidation. Workup as above yielded $26.0 \mathrm{mg}(98 \%)$ of $\mathbf{1 4}, 96: 4$ e.r. by chiral HPLC.

(R)-1-(tert-Butyldiphenylsilyoxy)-7-octen-4-ol (15). A solution of allylmagnesium bromide (1 $\mathrm{M}$ in $\left.\mathrm{Et}_{2} \mathrm{O}, 7.3 \mathrm{~mL}, 7.3 \mathrm{mmol}\right)$ was added dropwise to a stirred suspension of $\mathrm{CuCl}\left(\mathrm{Cu}_{2} \mathrm{Cl}_{2}, 76 \mathrm{mg}, 0.76 \mathrm{mmol}\right.$ of $\left.\mathrm{Cu}^{\mathrm{I}}\right)$ in anhydrous $\mathrm{THF}(12 \mathrm{~mL})$, at $-50{ }^{\circ} \mathrm{C}$ under $\mathrm{N}_{2}$ atmosphere. Then, a solution of $14(1.00 \mathrm{~g}, 2.94 \mathrm{mmol})$ in anhydrous THF $(6 \mathrm{~mL})$ was added via cannula and the reaction mixture was stirred at $-50{ }^{\circ} \mathrm{C}$ for 30 min. The reaction was quenched by addition of an aqueous $\mathrm{NaHCO}_{3}$ solution $(5 \%, 40 \mathrm{~mL})$ and $\mathrm{Et}_{2} \mathrm{O}(40 \mathrm{~mL})$. The layers were separated and 
the aqueous phase was extracted with $\mathrm{Et}_{2} \mathrm{O}(3 \times 40 \mathrm{~mL})$. The combined organic layers were dried over $\mathrm{MgSO}_{4}$ and filtered. The solvent was removed under reduced pressure and the residue was purified by column chromatography $\left(\mathrm{CH}_{2} \mathrm{Cl}_{2}\right.$ to $\left.99: 1 \mathrm{CH}_{2} \mathrm{Cl}_{2} / \mathrm{MeOH}\right)$ to afford $15(0.99 \mathrm{~g}$, 88\%) as a yellowish oil: $\mathrm{R}_{f}\left(\mathrm{CH}_{2} \mathrm{Cl}_{2}\right)$ 0.24; $[\alpha]_{\mathrm{D}}-0.84\left(c \mathrm{c} .8, \mathrm{CHCl}_{3}\right) ;{ }^{1} \mathrm{H}$ NMR $1.05(\mathrm{~s}, 9 \mathrm{H}), 1.45-1.62(\mathrm{~m}, 6 \mathrm{H}), 2.08-2.18(\mathrm{~m}, 2 \mathrm{H}), 3.62-3.66$ (m, 1H), $3.71(\mathrm{t}, J=7.8,2 \mathrm{H}), 4.98(\mathrm{ddt}, J=10.2,2.0,1.0,1 \mathrm{H}), 5.06(\mathrm{dq}, J=17.1,1.6,1 \mathrm{H}), 5.85(\mathrm{ddt}, J=17.1,10.2,6.7,1 \mathrm{H}), 7.36-7.47(\mathrm{~m}$, $6 \mathrm{H}), 7.66-7.71(\mathrm{~m}, 4 \mathrm{H})$. NMR data agree with those previously reported. ${ }^{28}$

(2S,5S)-5-[3-(tert-Butyldiphenylsilyloxy)propyl]tetrahydrofuran-2-methanol (16). Compound 15 (64.0 mg, 0.167 mmol), $\mathrm{CH}_{2} \mathrm{Cl}_{2}(0.9$ $\mathrm{mL}$ ), and $30 \%$ aqueous $\mathrm{H}_{2} \mathrm{O}_{2}$ (without stabilizers) $(0.110 \mathrm{~mL}, 1.0 \mathrm{mmol})$ were added to the complex of $\mathrm{Ti}^{\mathrm{IV}}$ and ent-cis-salalen catalyst $(0.05$ mmol, prepared as above from $\mathrm{Ti}\left(\mathrm{O}^{\mathrm{i}} \mathrm{Pr}\right)_{4}$ and the enantiomer of $c i s$-salalen, see Scheme 7). The reaction mixture was vigorously stirred at room temperature for 3 days, open to the air. More $\mathrm{H}_{2} \mathrm{O}_{2}$ was added each day, as above (up to 3 mmol, 18 equiv). The reaction was then diluted with $\mathrm{CH}_{2} \mathrm{Cl}_{2}(10 \mathrm{~mL})$ and $\mathrm{H}_{2} \mathrm{O}(10 \mathrm{~mL})$, the phases were separated and the organic phase was washed with brine $(2 \times 15 \mathrm{~mL})$, dried over $\mathrm{MgSO}_{4}$, and filtered. The solvent was removed under reduced pressure and the residue was analyzed by chiral HPLC (Chiralpack AS-H, hexanes/isopropanol 99:1, $0.6 \mathrm{~mL} / \mathrm{min}, \lambda=254 \mathrm{~nm}) \mathrm{t}_{\mathrm{R}}(S S)=22.6 \min (\geq 85 \%) ; \mathrm{t}_{\mathrm{R}}(R R)=23.6 \min (\leq 1 \%) ; \mathrm{t}_{\mathrm{R}}(R S), \mathrm{t}_{\mathrm{R}}(S R)=25.4 \min (7 \%)$ and $26.1 \mathrm{~min}(7 \%)$. The desired compound (16, major component of the residue) was isolated after flash chromatographic separation (hexanes/EtOAc, 85:15) as a yellowish oil: $51 \mathrm{mg}(76 \%) ; \mathrm{R}_{f}$ (hexanes/EtOAc, 7:3) 0.2; $[\alpha]_{\mathrm{D}}+4.38\left(c 1.00, \mathrm{CHCl}_{3}\right) ; \mathrm{IR}: 3420,1106,1006,822$; ${ }^{1} \mathrm{H}$ NMR 1.05 (s, 9H), 1.43-1.50 (m, 1H), 1.53-1.73 (m, 4H), 1.84-2.00 (m, 3H), $3.46(\mathrm{dd}, J=11.3,5.6,1 \mathrm{H}), 3.67-3.70(\mathrm{~m}, 3 \mathrm{H}), 3.83-3.89$ (m, 1H), 3.96-4.01 (m, 1H), 7.35-7.42 (m, 6H), 7.65-7.68 (m, 4H); ${ }^{13} \mathrm{C}$ NMR 19.2, 26.8, 27.0, 29.3, 31.4, 32.1, 63.7, 65.3, 79.2, 79.9, 127.6, 129.5, 133.9, 135.5; HRMS (ESI+) calcd for $\mathrm{C}_{24} \mathrm{H}_{35} \mathrm{O}_{3} \mathrm{Si}^{+}(\mathrm{M}+\mathrm{H})^{+}$399.2350, found 399.2345.

(2S,5S)-5-[3-(tert-Butyldiphenylsilyloxy)propyl]tetrahydrofuran-2-carboxaldehyde (17). A solution of $\mathbf{1 6}$ (50 $\mathrm{mg}, 0.13 \mathrm{mmol})$ in $\mathrm{CH}_{2} \mathrm{Cl}_{2}(1.3 \mathrm{~mL})$ was treated with DMP $(70 \mathrm{mg}, 0.20 \mathrm{mmol})$ at $0{ }^{\circ} \mathrm{C}$. After $3 \mathrm{~h}$ at $\mathrm{rt}$, the mixture was quenched with a saturated aqueous solution of $\mathrm{Na}_{2} \mathrm{~S}_{2} \mathrm{O}_{3}(10 \mathrm{~mL})$ and diluted with $\mathrm{Et}_{2} \mathrm{O}(10 \mathrm{~mL})$. The aqueous layer was extracted with $\mathrm{Et}_{2} \mathrm{O}(3 \times 10 \mathrm{~mL})$ and the combined organic extracts were washed with brine $\left(20 \mathrm{~mL}\right.$ ), dried over $\mathrm{Na}_{2} \mathrm{SO}_{4}$, and concentrated. The residue was purified on silica gel (hexanes/EtOAc, 7:3) to give $45 \mathrm{mg}(88 \%)$ of 17 as a yellow oil: $\mathrm{R}_{f}$ (hexanes/EtOAc, 7:3) 0.5; $[\alpha]_{\mathrm{D}}-19.4\left(c\right.$ 10.0, $\left.\mathrm{CHCl}_{3}\right) ;{ }^{1} \mathrm{H}$ NMR $1.05(\mathrm{~s}, 9 \mathrm{H}), 1.43(\mathrm{~m}, 1 \mathrm{H}), 1.56-$ $1.75(\mathrm{~m}, 4 \mathrm{H}), 1.95-2.17(\mathrm{~m}, 3 \mathrm{H}), 3.70(\mathrm{dd}, J=8.1,3.9,2 \mathrm{H}), 3.99-4.05(\mathrm{~m}, 1 \mathrm{H}), 4.22(\mathrm{ddd}, J=8.4,5.4,1.8,1 \mathrm{H}), 7.35-7.44(\mathrm{~m}, 6 \mathrm{H}), 7.65-7.68$ (m, 4H), $9.66(\mathrm{~d}, J=1.8,1 \mathrm{H}) ;{ }^{13} \mathrm{C}$ NMR 19.2, 26.8, 27.8, 29.2, 31.1, 31.9, 63.6, 81.1, 82.9, 127.6, 129.5, 133.9, 135.5, 203.3; HRMS (ESI+) calcd for $\mathrm{C}_{24} \mathrm{H}_{33} \mathrm{O}_{3} \mathrm{Si}^{+}(\mathrm{M}+\mathrm{H})^{+}$397.2193, found 397.2185.

(4S,7S)-8-Benzyloxy-7-(tert-butyldimethylsilyloxy)-1-octen-4-ol (19). To a stirred solution of aldehyde $\mathbf{1 8}^{20}$ (420 $\left.\mathrm{mg}, 1.30 \mathrm{mmol}\right)$ in anhydrous $\mathrm{Et}_{2} \mathrm{O}(2.3 \mathrm{~mL})$ at $-78^{\circ} \mathrm{C}$ was added (+)-Icp ${ }_{2} \mathrm{~B}$ (allyl) $(1.4 \mathrm{~mL}$ of $1 \mathrm{M}$ hexane solution, $1.4 \mathrm{mmol})$ diluted with $\mathrm{Et}_{2} \mathrm{O}(2 \mathrm{~mL})$. One hour later, a $3 \mathrm{M}$ solution of $\mathrm{NaOH}(0.5 \mathrm{~mL}, 1.6 \mathrm{mmol})$ was slowly added, followed by the addition of a $33 \%$ solution of $\mathrm{H}_{2} \mathrm{O}_{2}(0.5 \mathrm{~mL}, 4.9 \mathrm{mmol})$. After stirring at $\mathrm{rt}$ for $5 \mathrm{~h}$, the aqueous phase was extracted with $\mathrm{Et}_{2} \mathrm{O}(3 \times 20 \mathrm{~mL})$. The combined organic phases were washed with brine ( 30 $\mathrm{mL}$ ), dried over $\mathrm{MgSO}_{4}$, filtered, and concentrated. Flash column chromatography (hexanes/EtOAc, 7:3) afforded 19 (449 mg, 95\%): colorless

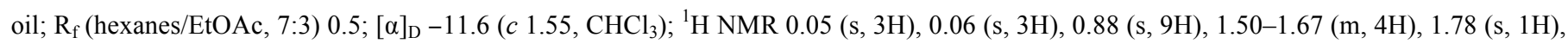
2.12-2.19 (m, 1H), 2.26-2.32 (m, 1H), $3.37(\mathrm{dd}, J=9.6,5.5), 3.42(\mathrm{dd}, 1 \mathrm{H}, J=9.6,5.5), 3.61-3.68(\mathrm{~m}, 1 \mathrm{H}), 3.84-3.90(\mathrm{~m}, 1 \mathrm{H}), 4.49-4.55(\mathrm{~m}$, 
2H), 5.10-5.11 (m, 1H), 5.13-5.15 (m, 1H), 5.77-5.88 (m, 1H), 7.27-7.37 (m, 5H); ${ }^{13} \mathrm{C}$ NMR -4.8, -4.3, 18.1, 25.9, 30.4, 32.0, 41.9, 70.6, 71.4, 73.3, 74.2, 117.8, 127.5, 127.6, 128.3, 134.9, 138.3; HRMS (ESI+) calcd for $\mathrm{C}_{21} \mathrm{H}_{37} \mathrm{O}_{3} \mathrm{Si}^{+}(\mathrm{M}+\mathrm{H})^{+} 365.2506$, found 365.2512.

(2S,5R)-2-(Phenylmethoxy)methyl-5-(2-propen-1-yl)tetrahydrofuran，(2R,5S)-2-allyl-5-[(benzyloxy)methyl]oxolane (20). Methanesulfonyl chloride ( $\mathrm{MsCl}, 129 \mu \mathrm{L}, 1.55 \mathrm{mmol})$ was added to a stirred solution of 19 (434 mg, $1.19 \mathrm{mmol})$ and $\mathrm{Et}_{3} \mathrm{~N}(248 \mu \mathrm{L}, 1.78 \mathrm{mmol})$ in $\mathrm{CH}_{2} \mathrm{Cl}_{2}(2.4 \mathrm{~mL})$ at $0{ }^{\circ} \mathrm{C}$. The reaction mixture was stirred for $2 \mathrm{~h}$ at $0{ }^{\circ} \mathrm{C}$ and for $2 \mathrm{~h}$ at $\mathrm{rt}$ and was then quenched with water $(10 \mathrm{~mL})$. The aqueous phase was extracted with $\mathrm{Et}_{2} \mathrm{O}(3 \times 10 \mathrm{~mL})$. The combined organic phases were washed with brine $(20 \mathrm{~mL})$, dried over $\mathrm{MgSO}_{4}$, and filtered. The solvent was removed under reduced pressure to obtain $518 \mathrm{mg}$ (98\%) of the Ms derivative of 19 (which was used in the next step without purification): colorless oil; $\mathrm{R}_{\mathrm{f}}$ (hexanes/EtOAc, 7:3) 0.5; ${ }^{1} \mathrm{H}$ NMR 0.04 (s, 3H), 0.05 (s, 3H), 0.87 (s, 9H), 1.57-1.80 (m, 4H), 2.47$2.49(\mathrm{~m}, 2 \mathrm{H}), 2.96(\mathrm{~s}, 3 \mathrm{H}), 3.30(\mathrm{dd}, J=9.6,5.9,1 \mathrm{H}), 3.37$ (dd, $J=9.5,5.4,1 \mathrm{H}), 3.81-3.89(\mathrm{~m}, 1 \mathrm{H}), 4.47-4.55(\mathrm{~m}, 2 \mathrm{H}), 4.70-4.78(\mathrm{~m}, 1 \mathrm{H})$, 5.12-5.13 (m, 1H), 5.16-5.19 (m, 1H), 5.71-5.85 (m, 1H), 7.27-7.38 (m, 5H); ${ }^{13} \mathrm{C}$ NMR -4.8, -4.3, 18.1, 25.9, 29.5, 29.8, 38.7, 39.1, 70.6, 73.3, 74.3, 82.7, 119.0, 127.5, 127.6, 128.3, 132.3, 138.2. Deprotection and cyclization. Tetrabutylammonium fluoride (TBAF· $3 \mathrm{H}_{2} \mathrm{O}, 664 \mathrm{mg}$, $2.10 \mathrm{mmol}$ ) was added to the preceding compound $(518 \mathrm{mg}, 1.17 \mathrm{mmol})$ in THF $(20 \mathrm{~mL})$. After stirring for $18 \mathrm{~h}$, the reaction was concentrated under reduced pressure and the residue was purified by flash column chromatography, using hexanes/EtOAc (8:2) as eluent, to afford tetrahydrofuran derivative $\mathbf{2 0}^{29}$ (263 mg, 92\% yield): colorless oil; $\mathrm{R}_{\mathrm{f}}$ (hexanes/EtOAc, 7:3) 0.6; IR 2854, 1641, 1090, 1028; [ $\left.\alpha\right]_{\mathrm{D}}-1.4(c$ 13.0, $\left.\mathrm{CHCl}_{3}\right)$; ${ }^{1} \mathrm{H}$ NMR 1.52-1.59 (m, 1H), 1.65-1.72 (m, 1H), 1.88-1.98 (m, 2H), 2.21-2.28 (m, 1H), 2.36-2.43 (m, 1H), 3.45 (dd, $J=10.0,4.9$, $1 \mathrm{H}), 3.50(\mathrm{dd}, J=10.0,5.8,1 \mathrm{H}), 3.90-3.97(\mathrm{~m}, 1 \mathrm{H}), 4.05-4.12(\mathrm{~m}, 1 \mathrm{H}), 4.54-4.62(\mathrm{~m}, 2 \mathrm{H}), 5.02-5.10(\mathrm{~m}, 2 \mathrm{H}), 5.82(\mathrm{tdd}, J=17.2,10.2,7.0$, 1H), 7.26-7.36 (m, 5H); ${ }^{13} \mathrm{C}$ NMR 28.1, 30.1, 40.2, 73.0, 73.3, 78.1, 79.2, 116.7, 127.5, 127.6, 128.3, 135.0, 138.4; HRMS (ESI+) calcd for $\mathrm{C}_{15} \mathrm{H}_{21} \mathrm{O}_{2}(\mathrm{M}+\mathrm{H})^{+} 233.1536$, found 233.1546 .

Conversion of 20 into 17. A $0.5 \mathrm{M}$ solution of 9-BBN in THF ( $2 \mathrm{~mL}, 1 \mathrm{mmol})$ was added dropwise to a stirring solution of 20 (122 mg, $0.57 \mathrm{mmol})$ in dry THF $(2 \mathrm{~mL})$ at $0{ }^{\circ} \mathrm{C}$ under $\mathrm{N}_{2}$. After $4 \mathrm{~h}$, the ice bath was removed and a $2 \mathrm{M}$ solution of $\mathrm{NaOH}(1.1 \mathrm{~mL}, 2.0 \mathrm{mmol})$ and $\mathrm{H}_{2} \mathrm{O}_{2}(33 \% \mathrm{w} / \mathrm{w}, 1.1 \mathrm{~mL}, 8.5 \mathrm{mmol})$ were added. After $18 \mathrm{~h}$ at rt, a saturated solution of $\mathrm{NaCl}(10 \mathrm{~mL})$ was added to the reaction mixture. The organic layer was separated and the aqueous phase was extracted with $\mathrm{CH}_{2} \mathrm{Cl}_{2}(3 \times 30 \mathrm{~mL})$. The organic layers were washed with brine, dried over anhydrous $\mathrm{MgSO}_{4}$, filtered, and concentrated. The residue was purified on silica gel $\left(\mathrm{CH}_{2} \mathrm{Cl}_{2} / \mathrm{MeOH}, 95: 5\right)$ to give the corresponding

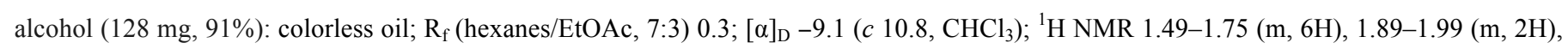
$3.47(\mathrm{~d}, J=5.4,2 \mathrm{H}), 3.65-3.68(\mathrm{~m}, 2 \mathrm{H}), 3.88-3.93(\mathrm{~m}, 1 \mathrm{H}), 4.08-4.14(\mathrm{~m}, 1 \mathrm{H}), 4.55(\mathrm{~d}, J=12.2,1 \mathrm{H}), 4.59(\mathrm{~d}, J=12.2,1 \mathrm{H}), 7.27-7.29(\mathrm{~m}$, 1H), 7.33-7.35 (m, 4H); ${ }^{13} \mathrm{C}$ NMR 28.0, 29.7, 31.0, 32.6, 62.8, 72.8, 73.3, 78.1, 80.0, 127.5, 127, 128.3, 138.3; HRMS (ESI+) calcd for $\mathrm{C}_{15} \mathrm{H}_{23} \mathrm{O}_{3}(\mathrm{M}+\mathrm{H})^{+} 251.1642$, found 251.1639. Silylation. Imidazole (132 mg, $\left.1.92 \mathrm{mmol}\right)$ was added to a stirred solution of the preceding alcohol $(240 \mathrm{mg}, 0.96 \mathrm{mmol})$ in THF $(4.8 \mathrm{~mL})$. Then TBDPSCl $(374 \mu \mathrm{L}, 1.44 \mathrm{mmol})$ was added dropwise at $0{ }^{\circ} \mathrm{C}$ and the resulting mixture was stirred at $\mathrm{rt}$ for $3 \mathrm{~h}$. The solution was poured into water $(20 \mathrm{~mL})$ and the aqueous phase was extracted with $\mathrm{CH}_{2} \mathrm{Cl}_{2}(3 \times 30 \mathrm{~mL})$. The combined organic extracts were washed with brine $(30 \mathrm{~mL})$, dried over $\mathrm{Na}_{2} \mathrm{SO}_{4}$, filtered, and concentrated. Flash column chromatography (hexanes/EtOAc, 9:1) afforded $462 \mathrm{mg}(98 \%)$ of the TBDPS-protected product: colorless oil; $\mathrm{R}_{\mathrm{f}}$ (hexanes/EtOAc, 7:3) 0.6; [ $\left.\alpha\right]_{\mathrm{D}}-2.0(c 1.25$, $\mathrm{CHCl}_{3}$ ); IR 2855, 1462, 1110, 1087; ${ }^{1} \mathrm{H}$ NMR $1.04(\mathrm{~s}, 9 \mathrm{H}), 1.04-1.72(\mathrm{~m}, 6 \mathrm{H}), 1.88-1.96(\mathrm{~m}, 2 \mathrm{H}), 3.43(\mathrm{dd}, J=10.0,4.9,1 \mathrm{H}), 3.47(\mathrm{dd}, J=$ 9.9, 5.9, 1H), 3.65-3.68 (m, 2H), 3.80-3.86 (m, 1H), 4.02-4.09 (m, 1H), 4.52-4.61 (m, 2H), 7.26-7.42 (m, 10H), 7.65-7.72 (m, 5H); ${ }^{13} \mathrm{C} \mathrm{NMR}$ 
$19.2,26.7,28.2,29.2,30.8,32.1,63.9,73.1,73.3,77.9,79.8,127.4,127.6,127.7,127.8,128.3,129.4,129.6,134.0,134.8,135.5,138.4$ HRMS (ESI+) calcd for $\mathrm{C}_{31} \mathrm{H}_{44} \mathrm{NO}_{3} \mathrm{Si}\left(M+\mathrm{NH}_{4}\right)^{+}$506.3085, found 506.3096. Cleavage of the benzyl ether. Palladium (10\% Pd/C, $60 \mathrm{mg}, 0.06$ mmol) was added to a solution of the TBDPS derivative (299 mg, $0.60 \mathrm{mmol})$ in absolute EtOH (4 mL) under a $\mathrm{N}_{2}$ atmosphere. After purging with hydrogen, the suspension was energetically stirred for $18 \mathrm{~h}$. The heterogeneous mixture was filtered under Celite ${ }^{\circledR}$ and washed with EtOH, and the solvent was evaporated under vacuum to afford the desired alcohol (215 $\mathrm{mg}, 88 \%)$ : yellowish oil; $\mathrm{R}_{\mathrm{f}}($ hexanes/EtOAc $7: 3) 0.2 ;[\alpha]_{\mathrm{D}}$ $+8.15\left(c\right.$ 1.06, $\left.\mathrm{CHCl}_{3}\right)$; IR 3420, 1106, 1006; ${ }^{1} \mathrm{H}$ NMR $1.05(\mathrm{~s}, 9 \mathrm{H}), 1.43-1.50(\mathrm{~m}, 1 \mathrm{H}), 1.53-1.71(\mathrm{~m}, 4 \mathrm{H}), 1.84-2.00(\mathrm{~m}, 3 \mathrm{H}), 3.46(\mathrm{dd}, J=$ $11.3,5.6,1 \mathrm{H}), 3.67-3.70(\mathrm{~m}, 3 \mathrm{H}), 3.83-3.89(\mathrm{~m}, 1 \mathrm{H}), 3.96-4.01(\mathrm{~m}, 1 \mathrm{H}), 7.35-7.42(\mathrm{~m}, 6 \mathrm{H}), 7.65-7.68(\mathrm{~m}, 4 \mathrm{H}) ;{ }^{13} \mathrm{C} \mathrm{NMR} 19.2,26.8,27.0$, $29.3,31.4,32.1,63.7,65.3,79.2,79.9,127.6,129.5,133.9,135.5$. Oxidation of the hydroxy group with Dess-Martin periodinane. A solution of the preceding alcohol $(50 \mathrm{mg}, 0.13 \mathrm{mmol})$ in $\mathrm{CH}_{2} \mathrm{Cl}_{2}(1.3 \mathrm{~mL})$ was treated with Dess-Martin periodinane $(70 \mathrm{mg}, 0.20 \mathrm{mmol})$ at 0 ${ }^{\circ} \mathrm{C}$. After $3 \mathrm{~h}$ at $\mathrm{rt}$, the mixture was quenched with a saturated solution of $\mathrm{Na}_{2} \mathrm{~S}_{2} \mathrm{O}_{3}(10 \mathrm{~mL})$ and diluted with $\mathrm{Et}_{2} \mathrm{O}(10 \mathrm{~mL})$. The aqueous layer was extracted with $\mathrm{Et}_{2} \mathrm{O}(3 \times 10 \mathrm{~mL})$ and the combined organic extracts were washed with brine $(20 \mathrm{~mL})$, dried over $\mathrm{Na}_{2} \mathrm{SO}_{4}$, filtered, and concentrated. The residue was purified on silica gel (hexanes/EtOAc, $7: 3$ ) to give 17 (49 $\mathrm{mg}, 82 \%$ ). Oxidation of the hydroxy group under the Swern conditions. Oxalyl dichloride $\left[(\mathrm{COCl})_{2}, 126 \mu \mathrm{L}, 1.2 \mathrm{mmol}\right]$ was added dropwise to a stirring solution of DMSO (195 $\left.\mu \mathrm{L}, 2.4 \mathrm{mmol}\right)$ in dry $\mathrm{CH}_{2} \mathrm{Cl}_{2}(4 \mathrm{~mL})$ at $-78{ }^{\circ} \mathrm{C}$ under $\mathrm{N}_{2}$. After $10 \mathrm{~min}$, the alcohol $(482 \mathrm{mg}, 1.2 \mathrm{mmol})$ in $\mathrm{CH}_{2} \mathrm{Cl}_{2}(4 \mathrm{~mL})$ was transferred via cannula, stirring was continued for $45 \mathrm{~min}$, and $\mathrm{Et}_{3} \mathrm{~N}(661 \mathrm{~mL}, 6.5 \mathrm{mmol})$ was then added dropwise and the reaction was stirred for $2 \mathrm{~h}$ at $\mathrm{rt}$. It was then diluted with $\mathrm{Et}_{2} \mathrm{O}(50 \mathrm{~mL})$ and the organic extract was washed with saturated $\mathrm{NaHCO}_{3}$ solution $(50 \mathrm{~mL})$, dried over $\mathrm{MgSO}_{4}$, filtered, and concentrated. Flash column chromatography (hexanes/EtOAc 8:2) afforded the desired aldehyde, 17 (460 mg, 96\%).

(R)-5-[(4-Bromo-2-methyl-4-penten-1-yl)thio]-1-phenyl-1H-tetrazole (22). Triphenylphosphine (275 mg, $1.05 \mathrm{mmol})$ and 1-phenyl-1Htetrazole-5-thiol (193 mg, $1.05 \mathrm{mmol})$ were added to a solution of alcohol $\mathbf{2 1}^{21}$ (125 $\left.\mathrm{mg}, 0.70 \mathrm{mmol}\right)$ in THF (7 mL). The mixture was cooled to $0{ }^{\circ} \mathrm{C}$ and $\mathrm{DEAD}, 40 \%$ in toluene, $564 \mu \mathrm{L}, 1.05 \mathrm{mmol}$ ) was added. After stirring for $1 \mathrm{~h}$, the solution was quenched by addition of a saturated aqueous solution of $\mathrm{NaHCO}_{3}(10 \mathrm{~mL})$. The aqueous phase was extracted with $\mathrm{CH}_{2} \mathrm{Cl}_{2}(3 \times 10 \mathrm{~mL})$ and the combined organic extracts were washed with brine $(15 \mathrm{~mL})$, dried over $\mathrm{MgSO}_{4}$, filtered, and concentrated under reduced pressure. The residue was purified by flash column chromatography (hexanes/EtOAc, 8:2) to obtain $199 \mathrm{mg}(84 \%)$ of 22 as a colorless oil: $\mathrm{R}_{f}\left(\right.$ hexanes/EtOAc, 8:2) $0.8 ;[\alpha]_{\mathrm{D}}-8.2\left(c 0.9, \mathrm{CHCl}_{3}\right)$; IR 1629, 1495, 1384; ${ }^{1} \mathrm{H}$ NMR $1.07(\mathrm{~d}, J=6.5,3 \mathrm{H}), 2.32-2.42(\mathrm{~m}, 2 \mathrm{H}), 2.59-2.66(\mathrm{~m}, 1 \mathrm{H}), 3.35(\mathrm{dd}, J=12.9,6.8,1 \mathrm{H}), 3.49(\mathrm{dd}, J=12.9,6.4$, $1 \mathrm{H}), 5.49(\mathrm{~d}, J=1.4,1 \mathrm{H}), 5.63(\mathrm{~m}, 1 \mathrm{H}), 7.55-7.61(\mathrm{~m}, 5 \mathrm{H}) ;{ }^{13} \mathrm{C}$ NMR $18.3,31.5,39.2,47.3,118.9,123.9,129.8,130.1,131.7,133.7,154.3$; HRMS (ESI+) calcd for $\mathrm{C}_{13} \mathrm{H}_{16}{ }^{79} \mathrm{BrN}_{4} \mathrm{~S}^{+}(\mathrm{M}+\mathrm{H})^{+} 339.0274$, found 339.0265.

(R)-5-(4-Bromo-2-methyl-4-penten-1-yl)sulfonyl-1-phenyl-1H-tetrazole (23). A solution of $22(100 \mathrm{mg}, 0.29 \mathrm{mmol})$ in EtOH (3 mL) at 0 ${ }^{\circ} \mathrm{C}$ was treated with ammonium heptamolybdate-tetrahydrate $(73 \mathrm{mg}, 0.06 \mathrm{mmol})$ in $\mathrm{H}_{2} \mathrm{O}_{2}(33 \% \mathrm{w} / \mathrm{w}, 276 \mu \mathrm{L}, 2.93 \mathrm{mmol})$. After stirring overnight at $\mathrm{rt}$ the resulting suspension, the solvent was evaporated and the residue was partitioned between water $(30 \mathrm{~mL})$ and $\mathrm{CH}_{2} \mathrm{Cl}_{2}(30$ $\mathrm{mL})$. The phases were separated and the aqueous layer was extracted with $\mathrm{CH}_{2} \mathrm{Cl}_{2}(3 \times 50 \mathrm{~mL})$. The combined organic extracts were dried over $\mathrm{MgSO}_{4}$, filtered, and concentrated. Flash chromatography (hexanes/EtOAc, 7:3) provided $101 \mathrm{mg}$ (93\%) of 23 as a colorless oil: $\mathrm{R}_{f}$ (hexanes/EtOAc, 8:2) 0.5; $[\alpha]_{\mathrm{D}}+1.5\left(c 0.9, \mathrm{CHCl}_{3}\right)$; IR 1629,1595, 1340, 1151; ${ }^{1} \mathrm{H}$ NMR $1.21(\mathrm{~d}, J=6.3,3 \mathrm{H}), 2.47(\mathrm{dd}, J=14.0,7.3,1 \mathrm{H})$, $2.65-2.78(\mathrm{~m}, 2 \mathrm{H}), 3.65(\mathrm{dd}, J=14.5,7.8,1 \mathrm{H}),, 3.84(\mathrm{dd}, J=14.5,5.6,1 \mathrm{H}), 5.54(\mathrm{~d}, J=1.7,1 \mathrm{H}), 5.66(\mathrm{br} \mathrm{s}, 1 \mathrm{H}), 7.60-7.64(\mathrm{~m}, 2 \mathrm{H}), 7.68-$ 
7.70 (m, 3H); ${ }^{13} \mathrm{C}$ NMR 19.1, 27.1, 47.7, 60.4, 120.0, 125.2, 129.7, 130.4, 131.5, 133.1, 154.0; HRMS (ESI+) calcd for $\mathrm{C}_{13} \mathrm{H}_{16}{ }^{79} \mathrm{BrN}_{4} \mathrm{O}_{2} \mathrm{~S}^{+}(\mathrm{M}+$ $\mathrm{H})^{+} 371.0172$, found 371.0185 .

$(2 S, 5 S)$-2-[(2E,3R)-5-Bromo-3-methyl-1,5-hexadienyl]-5-[(3-tert-butyldiphenylsilyloxy)propyl]tetrahydrofuran (24). ${ }^{6 \mathrm{~d}}$ A $0.5 \mathrm{M}$ solution of KHMDS in toluene $(2.2 \mathrm{~mL}, 1.1 \mathrm{mmol})$ was added dropwise to a stirred solution of sulfone $\mathbf{2 3}(434 \mathrm{mg}, 1.17 \mathrm{mmol})$ in DMF $(4 \mathrm{~mL})$ at $-65^{\circ} \mathrm{C}$ under Ar. After $30 \mathrm{~min}$ at $-65^{\circ} \mathrm{C}$, a solution of aldehyde $17(290 \mathrm{mg}, 0.73 \mathrm{mmol})$ in DMF (3.3 mL) was added dropwise. The reaction mixture was stirred for $18 \mathrm{~h}$ at $\mathrm{rt}$ and the reaction was then quenched with $\mathrm{H}_{2} \mathrm{O}(30 \mathrm{~mL})$ and $\mathrm{Et}_{2} \mathrm{O}(20 \mathrm{~mL})$. The aqueous phase was extracted with $\mathrm{Et}_{2} \mathrm{O}$ $(3 \times 20 \mathrm{~mL})$, the organic phases were combined and washed with brine $(30 \mathrm{~mL})$, dried over $\mathrm{Na}_{2} \mathrm{SO}_{4}$, filtered, and concentrated under reduced pressure. The residue was purified by flash column chromatography (hexanes/EtOAc, 9:1) to afford $320 \mathrm{mg}(80 \%)$ of $\mathbf{2 4}(96: 4 E / Z)$ as colorless oil, $\mathrm{R}_{f}$ (hexanes/EtOAc, 9:1) 0.6. Spectroscopic data as reported. ${ }^{6 \mathrm{~d}}$

Conversion of $27^{6 \mathrm{~d}}$ to 28. Ethyldiisopropylamine (diisopropylethylamine, DIPEA, $450 \mu \mathrm{L}, 2.58 \mathrm{mmol}$ ), NaI (64 $\mathrm{mg}, 0.43 \mathrm{mmol}$ ) and $\operatorname{MOMCl}(129 \mu \mathrm{L}, 139 \mathrm{mg}, 1.72 \mathrm{mmol})$ were added to a solution of $27(300 \mathrm{mg}, 0.43 \mathrm{mmol})$ in MeCN $(4.3 \mathrm{~mL})$. The mixture was heated to 50 ${ }^{\circ} \mathrm{C}$ for $3 \mathrm{~h}$. Afterwards the reaction was quenched by addition of a saturated aqueous solution of $\mathrm{NH}_{4} \mathrm{Cl}(20 \mathrm{~mL})$ and diluted with $\mathrm{CH}_{2} \mathrm{Cl}_{2}(20$ $\mathrm{mL})$. The organic layer was separated and the aqueous layer extracted with $\mathrm{CH}_{2} \mathrm{Cl}_{2}(3 \times 20 \mathrm{~mL})$. The combined organic phases were dried over $\mathrm{MgSO}_{4}$ and concentrated. The residue was purified on silica gel (hexanes/EtOAc, 8:2) to give, apart from $30 \mathrm{mg}$ of the starting material, the MOM-protected compound (287 mg, 90\%), (2S,5S)-2-[(1R,2R,3R)-2-bromo-2-(4-methoxybenzyloxy)-1-methoxymethoxy-3-methyl-5hexen-1-yl]-5-[3-(tert-butyldiphenylsilyloxy)propyl]tetrahydrofuran (so-called MOM-protected derivative 27a in the SI): colorless oil; $\mathrm{R}_{f}$ (hexanes/EtOAc, 8:2) 0.45; $[\alpha]_{\mathrm{D}}+3.1$ (c 1.46, $\mathrm{CHCl}_{3}$ ); IR (film) 2996, 2931, 2857, 1613, 1514; ${ }^{1} \mathrm{H}$ NMR 0.97 (d, $\left.J=6.6,3 \mathrm{H}\right), 1.05$ (s, 9H), $1.45-1.51(\mathrm{~m}, 1 \mathrm{H}), 1.58-1.81(\mathrm{~m}, 5 \mathrm{H}), 1.82-1.95(\mathrm{~m}, 2 \mathrm{H}), 2.18(\mathrm{dd}, J=14.0,10.6,1 \mathrm{H}), 2.24-2.35(\mathrm{~m}, 1 \mathrm{H}), 2.72(\mathrm{dd}, J=13.7,2.1,1 \mathrm{H}), 3.39-$ $3.45(\mathrm{~m}, 4 \mathrm{H}), 3.61(\mathrm{t}, J=5.5,1 \mathrm{H}), 3.65-3.72(\mathrm{~m}, 2 \mathrm{H}), 3.76-3.83(\mathrm{~m}, 4 \mathrm{H}), 4.02-4.10(\mathrm{~m}, 1 \mathrm{H}), 4.50(\mathrm{~d}, J=11.0,1 \mathrm{H}), 4.60(\mathrm{~d}, J=11.1,1 \mathrm{H})$, $4.78(\mathrm{~d}, J=6.8,1 \mathrm{H}), 4.85(\mathrm{~d}, J=6.8,1 \mathrm{H}), 5.42(\mathrm{~s}, 1 \mathrm{H}), 5.57(\mathrm{~s}, 1 \mathrm{H}), 6.84-6.89(\mathrm{~m}, 2 \mathrm{H}), 7.22-7.28(\mathrm{~m}, 2 \mathrm{H}), 7.34-7.44(\mathrm{~m}, 6 \mathrm{H}), 7.64-7.70(\mathrm{~m}$, 4H); ${ }^{13} \mathrm{C}$ NMR 16.0, 19.4, 26.9, 27.9, 29.4, 31.2, 32.1, 32.6, 43.8, 55.3, 56.2, 63.9, 73.1, 79.3, 79.5, 80.4, 83.2, 98.1, 113.7, 118.0, 127.6, 129.3, 129.5, 130.9, 134.1, 135.5, 159.1; HRMS (ESI+) calcd for $\mathrm{C}_{40} \mathrm{H}_{59}{ }^{79} \mathrm{BrNO}_{6} \mathrm{Si}^{+}\left(\mathrm{M}+\mathrm{NH}_{4}\right)^{+} 756.3290$, found 756.3293 .

A $1 \mathrm{M}$ solution of TBAF in THF ( $324 \mu \mathrm{L}, 0.324 \mathrm{mmol})$ was added to a solution of the previously prepared compound $(120 \mathrm{mg}, 0.162 \mathrm{mmol})$ in THF $(1.6 \mathrm{~mL})$ under $\mathrm{N}_{2}$ at $0{ }^{\circ} \mathrm{C}$. The reaction was stirred at $\mathrm{rt}$ for $2 \mathrm{~h}$. A saturated aqueous solution of $\mathrm{NH}_{4} \mathrm{Cl}(10 \mathrm{~mL})$ and $\mathrm{CH}_{2} \mathrm{Cl}_{2}(10 \mathrm{~mL})$ were added to the reaction and the layers were separated. The aqueous extract was washed with $\mathrm{CH}_{2} \mathrm{Cl}_{2}(2 \times 10 \mathrm{~mL})$ and the combined organic phases were dried over $\mathrm{Na}_{2} \mathrm{SO}_{4}$ and concentrated. The residue was purified on silica gel (hexanes/EtOAc, 9:1 to 6:4) to yield $76 \mathrm{mg}$ (94\%) of a colorless oil, $\quad(2 S, 5 S)-5-[(1 R, 2 R, 3 R)$-2-bromo-2-(4-methoxybenzyloxy)-1-methoxymethoxy-3-methyl-5-hexenyl]-5-(3-hydroxypropyl)tetrahydrofuran (so-called derivative 27b in the SI): $\mathrm{R}_{f}$ (hexanes:EtOAc, 8:2) 0.15; $[\alpha]_{\mathrm{D}}+3.2,\left(c 1.00, \mathrm{CHCl}_{3}\right)$; IR 3370, 2970, 1453; ${ }^{1} \mathrm{H}$ NMR $0.99(\mathrm{~d}, J=6.3,3 \mathrm{H})$, $1.50-1.75(\mathrm{~m}, 5 \mathrm{H}), 1.8-2.0(\mathrm{~m}, 3 \mathrm{H}), 2.16-2.30(\mathrm{~m}, 2 \mathrm{H}), 2.67(\mathrm{~d}, J=11.9,1 \mathrm{H}), 3.42(\mathrm{~s}, 3 \mathrm{H}), 3.49(\mathrm{dd}, J=6.0,4.7), 3.59-3.64(\mathrm{~m}, 1 \mathrm{H}), 3.64-3.77$ (m, 2H), $3.80(\mathrm{~s}, 3 \mathrm{H}), 3.84-3.93(\mathrm{~m}, 1 \mathrm{H}), 4.08-4.16(\mathrm{~m}, 1 \mathrm{H}), 4.52(\mathrm{~d}, J=11.0,1 \mathrm{H}), 4.63(\mathrm{~d}, J=11.0,1 \mathrm{H}), 4.80-4.85(\mathrm{~m}, 2 \mathrm{H}), 5.42(\mathrm{~s}, 1 \mathrm{H}), 5.57(\mathrm{~s}$, 1H), 6.85-6.89 (m, 2H), 7.24-7.28 (m, 2H); ${ }^{13} \mathrm{C}$ NMR 16.2, 27.6, 30.1, 31.5, 32.4, 32.7, 43.5, 55.2, 56.3, 62.7, 73.6, 79.5, 79.8, 80.3, 83.5, 98.3, 113.7, 118.1, 129.3, 130.8, 134.0, 159.1; HRMS (ESI+) calcd. for $\mathrm{C}_{24} \mathrm{H}_{41}{ }^{79} \mathrm{BrNO}_{6}{ }^{+}\left(\mathrm{M}+\mathrm{NH}_{4}\right)^{+} 518.2112$, found 518.2105. 
A $40 \%(w / w)$ solution of DEAD in toluene $(146 \mu \mathrm{L}, 0.31 \mathrm{mmol})$ was added dropwise to a stirring solution of the previously prepared primary alcohol $(84 \mathrm{mg}, 0.17 \mathrm{mmol}), \mathrm{PPh}_{3}(66 \mathrm{mg}, 0.25 \mathrm{mmol})$ and 1-phenyltetrazole-5-thiol $(45 \mathrm{mg}, 0.25 \mathrm{mmol})$ in $\mathrm{THF}(2 \mathrm{~mL})$ at $0{ }^{\circ} \mathrm{C}$. The ice bath was removed and, after stirring the mixture for $1 \mathrm{~h}$, the reaction was quenched with a saturated aqueous $\mathrm{NaHCO}_{3}$ solution $(25 \mathrm{~mL})$ and diluted with $\mathrm{CH}_{2} \mathrm{Cl}_{2}(25 \mathrm{~mL})$. The organic layer was separated and the aqueous layer extracted with $\mathrm{CH}_{2} \mathrm{Cl}_{2}(3 \times 10 \mathrm{~mL})$. The organic layers were collected, dried over anhydrous $\mathrm{Na}_{2} \mathrm{SO}_{4}$, and concentrated. The residue was purified on silica gel (hexanes/EtOAc, 7:3) to give $108 \mathrm{mg}$ (99\%) of a colorless oil, 5-\{[(1R,2R,3R)-5-bromo-2-(4-methoxybenzyloxy)-1-methoxymethoxy-3-methyl-5-hexen-1-yl]-3-[(2R,5S)-tetrahydrofuran-2-yl]propylthio\}-1-phenyl-1 $\boldsymbol{H}$-tetrazole (so-called thioether derivative $27 \mathrm{c}$ in the $\mathrm{SI}$ ): $\mathrm{R}_{f}\left(\right.$ hexanes/EtOAc, 5:5) 0.66 ; $[\alpha]_{\mathrm{D}}-5.5(c$ 0.90, $\mathrm{CHCl}_{3}$ ); IR (film) 3444, 1775, 1696; ${ }^{1} \mathrm{H}$ NMR 0.97 (d, $\left.J=6.5,3 \mathrm{H}\right), 1.47-2.01(\mathrm{~m}, 8 \mathrm{H}), 2.19(\mathrm{dd}, J=13.7,10.5,1 \mathrm{H}), 2.24-2.31(\mathrm{~m}, 1 \mathrm{H})$, $2.69(\mathrm{~d}, J=12.9,1 \mathrm{H}), 3.40(\mathrm{~s}, 3 \mathrm{H}), 3.45-3.50(\mathrm{~m}, 3 \mathrm{H}), 3.60(\mathrm{t}, J=5.4,1 \mathrm{H}), 3.80(\mathrm{~s}, 3 \mathrm{H}), 3.80-3.88(\mathrm{~m}, 1 \mathrm{H}), 4.09(\mathrm{ddd}, J=14.2,12.2,7.1$, $1 \mathrm{H}), 4.50(\mathrm{~d}, J=11.0,1 \mathrm{H}), 4.60(\mathrm{~d}, J=11.0,1 \mathrm{H}), 4.79(\mathrm{~d}, J=6.8,1 \mathrm{H}), 4.82(\mathrm{~d}, J=6.8,1 \mathrm{H}), 5.41(\mathrm{~s}, 1 \mathrm{H}), 5.57(\mathrm{~s}, 1 \mathrm{H}), 6.84-6.90(\mathrm{~m}, 2 \mathrm{H})$, 7.22-7.27 (m, 2H), 7.49-7.61 (m, 5H); ${ }^{13} \mathrm{C}$ NMR 16.1, 26.1, 27.7, 31.2, 32.6, 33.4, 34.4, 43.6, 55.3, 56.3, 73.3, 78.8, 79.5, 80.3, 83.3, 98.1, 113.7, 118.1, 123.9, 129.3, 129.7, 130.0, 130.8, 133.7, 134.0, 154.4, 159.1; HRMS (ESI+) calcd for $\mathrm{C}_{31} \mathrm{H}_{42}{ }^{79} \mathrm{BrN}_{4} \mathrm{O}_{5} \mathrm{~S}^{+}(\mathrm{M}+\mathrm{H})^{+} 661.2054$, found 661.2051 .

A solution of the sulfide prepared above $(30 \mathrm{mg}, 0.04 \mathrm{mmol})$ in $\mathrm{EtOH}(0.4 \mathrm{~mL})$ at $0{ }^{\circ} \mathrm{C}$ was treated with ammonium heptamolybdatetetrahydrate $(6 \mathrm{mg}, 0.004 \mathrm{mmol})$ in $\mathrm{H}_{2} \mathrm{O}_{2}(33 \% \mathrm{w} / \mathrm{w}, 0.05 \mathrm{~mL}, 0.4 \mathrm{mmol})$. After stirring overnight at $\mathrm{rt}$ the resulting suspension, the solvent was evaporated and the residue was partitioned between water $(10 \mathrm{~mL})$ and $\mathrm{CH}_{2} \mathrm{Cl}_{2}(10 \mathrm{~mL})$. The phases were separated and the aqueous layer was extracted with $\mathrm{CH}_{2} \mathrm{Cl}_{2}(3 \times 5 \mathrm{~mL})$. The combined organic extracts were dried over $\mathrm{MgSO}_{4}$, filtered, and concentrated. Flash column chromatography (hexanes/EtOAc, 7:3) provided $27 \mathrm{mg}(90 \%)$ of a colorless oil, 5-\{[(1R,2R,3R)-5-bromo-2-(4-methoxybenzyloxy)-1methoxymethoxy-3-methyl-5-hexen-1-yl]-3-[(2R,5S)-tetrahydrofuran-2-yl]propylsulfonyl\}-1-phenyl-1 $H$-tetrazole (so-called sulfone derivative 27d in the SI): $\mathrm{R}_{f}$ (hexanes/ EtOAc, 9:1) 0.2; $[\alpha]_{\mathrm{D}}-8.9$ ( $c$ 1.60, $\mathrm{CHCl}_{3}$ ); IR (film) 3444, 1775, 1696; ${ }^{1} \mathrm{H}$ NMR $0.98(\mathrm{~d}, J=6.2,3 \mathrm{H}), 1.53-1.62$ (m, 2H), 1.73-1.80 (m, 1H), 1.84-1.92 (m, 2H), 1.94-1.98 (m, 1H), 2.07-2.17 (m, 2H), 2.20-2.28 (m, 2H), 2.65 (d, J=11.3, 1H), 3.41 (s, 3H), $3.50(\mathrm{dd}, J=6.3,4.3,1 \mathrm{H}), 3.60(\mathrm{dd}, J=6.3,4.3,1 \mathrm{H}), 3.80(\mathrm{~s}, 3 \mathrm{H}), 3.88-3.92(\mathrm{~m}, 3 \mathrm{H}), 4.07-4.14(\mathrm{~m}, 1 \mathrm{H}), 4.52(\mathrm{~d}, J=11.0,1 \mathrm{H}), 4.62(\mathrm{~d}, J=$ 11.0, 1H), $4.78(\mathrm{~d}, J=6.8,1 \mathrm{H}), 4.81(\mathrm{~d}, J=6.8,1 \mathrm{H}), 5.42(\mathrm{~s}, 1 \mathrm{H}), 5.57(\mathrm{~s}, 1 \mathrm{H}), 6.84-6.88(\mathrm{~m}, 2 \mathrm{H}), 7.24-7.27(\mathrm{~m}, 2 \mathrm{H}), 7.64-7.56(\mathrm{~m}, 3 \mathrm{H})$, 7.67-7.71 (m, 2H); ${ }^{13} \mathrm{C}$ NMR 16.1, 19.4, 27.6, 31.0, 32.7, 33.5, 43.4, 55.3, 56.0, 56.3, 73.7, 78.6, 79.4, 80.3, 83.6, 98.3, 113.7, 118.1, 125.0, 129.3, 129.7, 130.9, 131.4, 133.0, 134.0, 153.5, 159.1; HRMS (ESI+) calcd for $\mathrm{C}_{31} \mathrm{H}_{42}{ }^{79} \mathrm{BrN}_{4} \mathrm{O}_{7} \mathrm{~S}^{+}(\mathrm{M}+\mathrm{H})^{+}$693.1952, found 693.1949 .

DDQ (34 mg, $0.15 \mathrm{mmol})$ was added to a solution of the sulfone prepared above $(78 \mathrm{mg}, 0.11 \mathrm{mmol})$ in a mixture of $\mathrm{CH}_{2} \mathrm{Cl}_{2}(1.8 \mathrm{~mL})$ and $\mathrm{pH} 7$ buffer $(0.2 \mathrm{~mL})$. After $30 \mathrm{~min}$ the reaction was quenched by addition of a saturated $\mathrm{NaHCO}_{3}$ solution $(10 \mathrm{~mL})$ and diluted with $\mathrm{CH}_{2} \mathrm{Cl}_{2}(10 \mathrm{~mL})$. The organic layer was separated and the aqueous layer extracted with $\mathrm{CH}_{2} \mathrm{Cl}_{2}(3 \times 10 \mathrm{~mL})$, dried over $\mathrm{MgSO}_{4}$, concentrated, and purified on silica gel (hexanes/EtOAc, $8: 2$ to 7:3) to afford $\mathbf{2 6}(63 \mathrm{mg}, 95 \%)$ as a yellowish oil, 5-\{[(1R,2R,3R)-5-bromo-2-hydroxy-1-methoxymethoxy-3-methyl5-hexen-1-yl]-3-[(2R,5S)-tetrahydrofuran-2-yl]propylsulfonyl\}-1-phenyl-1H-tetrazole (28): $\mathrm{R}_{f}\left(\right.$ hexanes/EtOAc, 5:5) 0.30; $[\alpha]_{\mathrm{D}}-25.1$ (c 0.68 , $\left.\mathrm{CHCl}_{3}\right) ;{ }^{1} \mathrm{H}$ NMR $0.91(\mathrm{~d}, J=6.3,3 \mathrm{H}), 1.05-1.67(\mathrm{~m}, 2 \mathrm{H}), 1.67-1.79(\mathrm{~m}, 2 \mathrm{H}), 1.92-2.03(\mathrm{~m}, 2 \mathrm{H}), 2.02-2.20(\mathrm{~m}, 5 \mathrm{H}), 2.62(\mathrm{~d}, J=8.2,1 \mathrm{H})$, $2.89(\mathrm{~d}, J=12.5,1 \mathrm{H}), 3.28(\mathrm{td}, J=7.9,2.6,1 \mathrm{H}), 3.43(\mathrm{~s}, 3 \mathrm{H}), 3.57(\mathrm{dd}, J=6.3,2.7,1 \mathrm{H}), 3.81-3.86(\mathrm{~m}, 2 \mathrm{H}), 3.87-3.93(\mathrm{~m}, 1 \mathrm{H}), 4.05-4.17(\mathrm{~m}$, $1 \mathrm{H}), 4.73(\mathrm{~d}, J=6.8,1 \mathrm{H}), 4.92(\mathrm{~d}, J=6.8,1 \mathrm{H}), 5.44(\mathrm{~s}, 1 \mathrm{H}), 5.60(\mathrm{~s}, 1 \mathrm{H}), 7.56-7.64(\mathrm{~m}, 3 \mathrm{H}), 7.67-7.71(\mathrm{~m}, 2 \mathrm{H}) ;{ }^{13} \mathrm{C}$ NMR 15.2, 19.3, 27.8, 
$30.7,33.7,34.2,40.0,55.8,56.3,75.7,78.7,80.1,80.6,97.6,118.1,125.0,129.7,131.4,133.0,134.0,153.4$; HRMS (ESI+) calcd for $\mathrm{C}_{23} \mathrm{H}_{37}{ }^{79} \mathrm{BrN}_{5} \mathrm{O}_{6} \mathrm{~S}^{+}\left(\mathrm{M}+\mathrm{NH}_{4}\right)^{+} 590.1642$, found 590.1646 .

5-\{[(1R,2R,3R)-5-Bromo-2-(tert-butyldiphenylsilyloxy)-1-methoxymethoxy-3-methyl-5-hexen-1-yl]-3-[(2R,5S)-tetrahydrofuran-2-yl]propylsulfonyl\}-1-phenyl-1H-tetrazole (29). tert-Butyldiphenylsilyl trifluorosulfonate (TBDPSOTf, $122 \mu \mathrm{L}, 0.36$ mmol) was added dropwise to a stirring solution of alcohol $28(70 \mathrm{mg}, 0.12 \mathrm{mmol})$ and 2,6-lutidine (52 $\mu \mathrm{L}, 0.49 \mathrm{mmol})$ in $\mathrm{CH}_{2} \mathrm{Cl}_{2}(0.9 \mathrm{~mL})$ under $\mathrm{N}_{2}$. After stirring overnight the reaction at $\mathrm{rt}$, it was quenched with a saturated aqueous solution of $\mathrm{NaHCO}_{3}(15 \mathrm{~mL})$ and diluted with $\mathrm{CH}_{2} \mathrm{Cl}_{2}(15 \mathrm{~mL})$. The layers were separated and the aqueous phase was extracted with $\mathrm{CH}_{2} \mathrm{Cl}_{2}(3 \times 20 \mathrm{~mL})$. The combined organic extracts were dried over $\mathrm{Na}_{2} \mathrm{SO}_{4}$ and concentrated. The residue was purified on silica gel (hexanes/EtOAc, 8:2) to recover $\mathbf{2 8}(5 \mathrm{mg}, \mathbf{7} \%)$ and to isolate $\mathbf{2 9}(82 \mathrm{mg}, 83 \%, 89 \%$ brsm): yellowish oil; $\mathrm{R}_{f}$ (hexanes/EtOAc, 7:3) 0.5; $[\alpha]_{\mathrm{D}}+0.77\left(c\right.$ 0.52, $\left.\mathrm{CHCl}_{3}\right)$; IR 2930, 1637, 1340, 1151, 1104, 1073, 1037, 703; ${ }^{1} \mathrm{H} \mathrm{NMR}$ $0.84(\mathrm{~d}, J=6.8,3 \mathrm{H}), 1.08(\mathrm{~s}, 9 \mathrm{H}), 1.37-1.45(\mathrm{~m}, 1 \mathrm{H}), 1.57-1.70(\mathrm{~m}, 2 \mathrm{H}), 1.74(\mathrm{q}, J=7.5,2 \mathrm{H}), 1.84-1.90(\mathrm{~m}, 1 \mathrm{H}), 1.90-1.99(\mathrm{~m}, 1 \mathrm{H}), 1.99-$ $2.11(\mathrm{~m}, 2 \mathrm{H}), 2.17-2.24(\mathrm{~m}, 1 \mathrm{H}), 2.79-2.86(\mathrm{~m}, 1 \mathrm{H}), 3.22(\mathrm{~s}, 3 \mathrm{H}), 3.47(\mathrm{dd}, J=5.7,3.6,1 \mathrm{H}), 3.75(\mathrm{dd}, J=5.9,3.6,1 \mathrm{H}), 3.78-3.85(\mathrm{~m}, 3 \mathrm{H})$, 4.06-4.13 (m, 1H), 4.41-4.49 (m, 2H), $5.34(\mathrm{~s}, 1 \mathrm{H}), 5.43(\mathrm{~s}, 1 \mathrm{H}), 7.35-7.45(\mathrm{~m}, 6 \mathrm{H}), 7.58-7.63(\mathrm{~m}, 3 \mathrm{H}), 7.67-7.72(\mathrm{~m}, 6 \mathrm{H}) ;{ }^{13} \mathrm{C} \mathrm{NMR} \mathrm{16.0,}$ $19.3,19.7,27.3,28.0,31.0,33.8,34.3,44.8,55.7,56.0,77.2,78.2,78.6,81.8,97.3,117.7,125.1,127.5,127.6,129.7,129.8,131.4,133.1$, 133.6, 133.6, 134.2, 136.2, 136.3, 153.5. HRMS (ESI+) calcd for $\mathrm{C}_{39} \mathrm{H}_{55} \mathrm{BrN}_{5} \mathrm{O}_{6} \mathrm{SSi}^{+}\left(\mathrm{M}+\mathrm{NH}_{4}\right)^{+}$828.2820, found 828.2811.

Compound 30. A $0.50 \mathrm{M}$ solution of KHMDS in toluene ( $400 \mu \mathrm{L}, 0.20 \mathrm{mmol}$ ) was added dropwise to a stirred solution of sulfone 29 (190 $\mathrm{mg}, 0.23 \mathrm{mmol})$ and 18 -crown-6 $(30 \mathrm{mg}, 0.20 \mathrm{mmol})$ in anhydrous DMF $(0.9 \mathrm{~mL})$ at $-65^{\circ} \mathrm{C}$ under Ar. Aldehyde $12(57 \mathrm{mg}, 0.12 \mathrm{mmol}) \mathrm{in}$ anhydrous DMF $(0.5 \mathrm{~mL})$ was slowly added via syringe. The reaction mixture was allowed to warm to $\mathrm{rt}$ and stirred for $12 \mathrm{~h}$. It was then quenched with pH 7 buffer $(20 \mathrm{~mL})$ and diluted with $\mathrm{Et}_{2} \mathrm{O}(20 \mathrm{~mL})$. The aqueous phase was extracted with $\mathrm{Et}_{2} \mathrm{O}(3 \times 10 \mathrm{~mL})$, the combined organic phases were washed with brine $(30 \mathrm{~mL})$, dried over $\mathrm{Na}_{2} \mathrm{SO}_{4}$, filtered, and concentrated under reduced pressure. The residue was purified by flash column chromatography (hexanes/EtOAc, 9:1 to 7:3) to afford $\mathbf{3 0}$ (72 $\mathrm{mg}, 68 \%$ ) with recovery of 29 (90-100 mg). Data for 30: colorless oil; $\mathrm{R}_{f}$ (hexanes/EtOAc, 9:1) 0.45; $[\alpha]_{\mathrm{D}}-2.3\left(c 0.59, \mathrm{CHCl}_{3}\right)$; IR 2957, 2930, 2856, 1624, 1472, 1427, 1383, 1241, 1150, 1111, 1050; ${ }^{1} \mathrm{H}$ NMR $0.84(\mathrm{~d}, J=6.8,3 \mathrm{H}), 1.03(\mathrm{~d}, J=6.6,3 \mathrm{H}), 1.04(\mathrm{~s}, 9 \mathrm{H}), 1.09(\mathrm{~s}, 9 \mathrm{H}), 1.29-1.39(\mathrm{~m}, 1 \mathrm{H}), 1.43-1.49(\mathrm{~m}, 7 \mathrm{H}), 1.54-1.60(\mathrm{~m}$, 1H), 1.72-1.77 (m, 2H), 1.80-1.86 (m, 1H), $1.90(\mathrm{dd}, J=14.1,10.7,1 \mathrm{H}), 2.05-2.10(\mathrm{~m}, 2 \mathrm{H}), 2.18-2.24(\mathrm{~m}, 1 \mathrm{H}), 2.37-2.47(\mathrm{~m}, 1 \mathrm{H}), 2.77-2.81$ (m, 1H), $3.23(\mathrm{~s}, 3 \mathrm{H}), 3.47-3.56(\mathrm{~m}, 3 \mathrm{H}), 3.72-3.76(\mathrm{~m}, 2 \mathrm{H}), 4.02-4.11(\mathrm{~m}, 3 \mathrm{H}), 4.49,4.52\left(\mathrm{AB}_{\mathrm{q}}, J=6.6,2 \mathrm{H}\right), 5.34(\mathrm{~s}, 1 \mathrm{H}), 5.38-5.45(\mathrm{~m}$, 2H), $5.50(\mathrm{dd}, J=15.2,6.8,1 \mathrm{H}), 5.64(\mathrm{dd}, J=15.3,7.3,1 \mathrm{H}), 5.78(\mathrm{dt}, J=15.0,6.6,1 \mathrm{H}), 6.05(\mathrm{dd}, J=15.4,10.4,1 \mathrm{H}), 6.25(\mathrm{dd}, J=15.2,10.4$, 1H), 7.34-7.45 (m, 12H), 7.63-7.67 (m, 4H), 7.67-7.72 (m, 4H); ${ }^{13} \mathrm{C}$ NMR 15.7, 16.3, 19.3, 19.7, 26.9, 27.0, 27.1, 27.3, 28.0, 29.0, 31.1, 34.5, $35.1,39.3,44.9,55.6,68.4,77.1,78.4,78.7,81.7,82.0,82.3,97.3,108.6,117.6,125.8,126.6,127.5,127.6,128.9,129.5,129.7,129.7,133.6$, 133.7, 133.8, 133.9, 134.2, 134.2, 135.6, 135.6, 136.2, 136.2, 136.3, 138.4; HRMS (ESI+) calcd for $\mathrm{C}_{61} \mathrm{H}_{87} \mathrm{BrNO}_{7} \mathrm{Si}_{2}^{+}\left(\mathrm{M}^{+} \mathrm{NH}_{4}\right)^{+} 1080.5199$, found 1080.5212 .

Compound 32. A mixture of $\mathbf{3 0}(68 \mathrm{mg}, 0.06 \mathrm{mmol})$, organotrifluoroborate $31^{6 \mathrm{~d}}(30 \mathrm{mg}, 0.15 \mathrm{mmol}), \mathrm{Pd}(\mathrm{OAc})_{2}(4.3 \mathrm{mg}, 0.02 \mathrm{mmol}), \mathrm{PPh}_{3}$ (10 mg, $0.03 \mathrm{mmol})$ and $\mathrm{Cs}_{2} \mathrm{CO}_{3}(62 \mathrm{mg}, 0.2 \mathrm{mmol})$ in degassed $\mathrm{THF} / \mathrm{H}_{2} \mathrm{O}(10: 1,1.3 \mathrm{~mL})$ was heated for $4 \mathrm{~h}$ at $70{ }^{\circ} \mathrm{C}$ under $\mathrm{Ar}$. The reaction was then quenched with water $(20 \mathrm{~mL})$ and diluted with $\mathrm{Et}_{2} \mathrm{O}(10 \mathrm{~mL})$. The organic layer was separated and the aqueous layer extracted with $\mathrm{Et}_{2} \mathrm{O}(3 \times 10 \mathrm{~mL})$. The combined organic extracts were dried over $\mathrm{Na}_{2} \mathrm{SO}_{4}$ and concentrated. The residue was purified on silica gel 
(hexanes/EtOAc, 9:1) to give $64 \mathrm{mg}(95 \%)$ of 32 as a yellowish oil: $\mathrm{R}_{f}$ (hexanes/EtOAc, 9:1) 0.45; $[\alpha]_{\mathrm{D}}-3.5\left(c\right.$ 1.5, $\mathrm{CHCl}_{3}$ ); IR 3071, 2957, 2929, 2856, 1653, 1590, 1471, 1461, 1427, 1377, 1110; ${ }^{1} \mathrm{H}$ NMR 0.83 (d, $\left.J=6.7,3 \mathrm{H}\right), 1.00-1.05$ (m, 12H), 1.08 (s, 9H), 1.28-1.36 (m, 1H), $1.43(\mathrm{br} \mathrm{s}, 6 \mathrm{H}), 1.47-1.86(\mathrm{~m}, 6 \mathrm{H}), 1.69(\mathrm{~s}, 3 \mathrm{H}), 1.97-2.12(\mathrm{~m}, 3 \mathrm{H}), 2.38-2.48(\mathrm{~m}, 1 \mathrm{H}), 2.69$ (br d, $J=14.0,1 \mathrm{H}), 2.74(\mathrm{~d}, J=7.3,2 \mathrm{H}), 3.23(\mathrm{~s}$, 3H), 3.45-3.56 (m, 3H), 3.68-3.73 (m, 2H), 3.96-4.12 (m, 3H), 4.50-4.54 (m, 2H), 4.70 (s, 1H), $4.73(\mathrm{~s}, 1 \mathrm{H}), 4.74$ (s, 1H), 4.89 (s, 1H), 5.40 (dd, $J=15.3,7.2,1 \mathrm{H}), 5.50(\mathrm{dd}, J=15.1,6.8,1 \mathrm{H}), 5.60-5.70(\mathrm{~m}, 2 \mathrm{H}), 5.77$ (dt, $J=15.3,6.7,1 \mathrm{H}), 5.99(\mathrm{~d}, J=15.9,1 \mathrm{H}), 6.05$ (dd, $J=15.3$, $10.4,1 \mathrm{H}), 6.25(\mathrm{dd}, J=15.1,10.4,1 \mathrm{H}), 7.33-7.44(\mathrm{~m}, 12 \mathrm{H}), 7.61-7.67$ (m, 4H), 7.67-7.77 (m, 4H); ${ }^{13} \mathrm{C}$ NMR 16.1, 16.3, 19.3, 19.7, 22.5, 26.9, 27.1, 27.2, 27.6, 27.9, 29.1, 31.1, 35.0, 35.2, 36.5, 39.3, 41.4, 55.6, 68.4, 78.0, 78.3, 79.2, 81.8, 82.0, 82.3, 97.3, 108.6, 110.8, 115.1, 125.7, 126.6, 127.6, 127.6, 127.7, 128.9, 129.5, 133.7, 133.8, 133.9, 134.9, 135.6, 136.2, 136.4, 138.3, 144.6, 144.7; HRMS (ESI+) calcd for $\mathrm{C}_{67} \mathrm{H}_{96} \mathrm{NO}_{7} \mathrm{Si}_{2}{ }^{+}\left(\mathrm{M}+\mathrm{NH}_{4}\right)^{+}$1082.6720, found 1082.6710.

Alcohol 33. A $1 \mathrm{M}$ solution of TBAF in THF ( $31 \mu \mathrm{L}, 0.03 \mathrm{mmol})$ was added to a solution of $32(30 \mathrm{mg}, 0.28 \mathrm{mmol})$ in THF (2.8 $\mathrm{mL})$ under Ar at $0{ }^{\circ} \mathrm{C}$. After $10 \mathrm{~h}$ at $\mathrm{rt}$ (or after $18 \mathrm{~h}$ at $4{ }^{\circ} \mathrm{C}$ ), $\mathrm{SiO}_{2}$ was added to the reaction and the solvent was removed under reduced pressure. The residue was purified on silica gel (hexanes/EtOAc, 8:2) to yield $22 \mathrm{mg}(97 \%)$ of 33 as a yellowish oil: $\mathrm{R}_{f}$ (hexanes/EtOAc, 7:3) 0.45; $[\alpha]_{\mathrm{D}}+3.7$ (c 0.78, $\mathrm{CHCl}_{3}$ ); IR 3481, 2928, 2856, 1458, 1427, 1376, 1217, 1105, 1038; ${ }^{1} \mathrm{H}$ NMR 0.83 (d, $\left.J=6.7,3 \mathrm{H}\right), 1.01$ (d, $\left.J=6.8,3 \mathrm{H}\right), 1.08$ (s, 9H), $1.30-1.37(\mathrm{~m}, 1 \mathrm{H}), 1.39-1.45(\mathrm{~m}, 1 \mathrm{H}), 1.43(\mathrm{~s}, 6 \mathrm{H}), 1.52-1.66(\mathrm{~m}, 3 \mathrm{H}), 1.70(\mathrm{~s}, 3 \mathrm{H}), 1.70-1.82(\mathrm{~m}, 2 \mathrm{H}), 1.95-2.13(\mathrm{~m}, 3 \mathrm{H}), 2.37-2.47$ (m, $1 \mathrm{H}), 2.68(\mathrm{~m}, 1 \mathrm{H}) 2.74(\mathrm{~d}, J=7.1,2 \mathrm{H}), 3.24(\mathrm{~s}, 3 \mathrm{H}), 3.43(\mathrm{dd}, J=10.4,7.4,1 \mathrm{H}), 3.48-3.54(\mathrm{~m}, 2 \mathrm{H}), 3.69-3.75(\mathrm{~m}, 2 \mathrm{H}), 3.98-4.10(\mathrm{~m}, 3 \mathrm{H})$, $4.52(\mathrm{~m}, 2 \mathrm{H}), 3.98-4.10(\mathrm{~m}, J=11.7,2 \mathrm{H}), 4.52(\mathrm{~m}, 2 \mathrm{H}), 4.70(\mathrm{~s}, 1 \mathrm{H}), 4.73(\mathrm{~s}, 1 \mathrm{H}), 4.74$ (s, 1H), 4.89 (s, 1H), 5.40 (dd, $J=15.3,7.2,1 \mathrm{H})$, $5.51-5.68(\mathrm{~m}, 3 \mathrm{H}), 5.76(\mathrm{dt}, J=15.4,6.7,1 \mathrm{H}), 5.99(\mathrm{~d}, J=15.8,1 \mathrm{H}), 6.14(\mathrm{dd}, J=15.3,10.3,1 \mathrm{H}), 6.28(\mathrm{dd}, J=15.2,10.5,1 \mathrm{H}), 7.34-7.43(\mathrm{~m}$, 6H), 7.66-7.76 (m, 4H); ${ }^{13} \mathrm{C}$ NMR 16.1, 16.3, 19.7, 22.5, 27.0, 27.1, 27.3, 27.9, 29.0, 31.0, 35.0, 35.2, 36.5, 39.7, 41.4, 55.6, 67.2, 78.0, 78.3, $79.2,81.7,82.0,82.3,97.3,108.6,110.8,115.1,125.6,127.4,127.4,127.5,127.7,129.6,129.7,130.2,133.6,133.7,133.9,133.9,136.2$, 136.4, 136.4, 137.7, 144.6, 144.7; HRMS (ESI+) calcd for $\mathrm{C}_{51} \mathrm{H}_{78} \mathrm{NO}_{7} \mathrm{Si}^{+}\left(\mathrm{M}+\mathrm{NH}_{4}\right)^{+} 844.5542$, found 844.5539.

Acid 34. A mixture of $33(22 \mathrm{mg}, 0.02 \mathrm{mmol})$, dry $\mathrm{NaHCO}_{3}(20 \mathrm{mg}, 0.10 \mathrm{mmol})$, and $\mathrm{CH}_{2} \mathrm{Cl}_{2}(0.6 \mathrm{~mL})$ was treated with DMP (stored over $\mathrm{P}_{4} \mathrm{O}_{10}$ under vacuum, $15.0 \mathrm{mg}, 0.035 \mathrm{mmol}$ ) under Ar at $\mathrm{rt}$. After stirring for $1 \mathrm{~h}$, the mixture was quenched with a saturated aqueous solution of $\mathrm{Na}_{2} \mathrm{~S}_{2} \mathrm{O}_{3}(20 \mathrm{~mL})$ and diluted with $\mathrm{Et}_{2} \mathrm{O}(20 \mathrm{~mL})$, and the aqueous layer was extracted with $\mathrm{Et}_{2} \mathrm{O}(3 \times 10 \mathrm{~mL})$. The organic extracts were dried over $\mathrm{MgSO}_{4}$ and concentrated. The crude aldehyde obtained was dissolved in ${ }^{t} \mathrm{BuOH}(1.4 \mathrm{~mL})$. 2-Methyl-2-butene (130 $\left.\mu \mathrm{L}, 86 \mathrm{mg}, 1.2 \mathrm{mmol}\right)$, isoprene $(25 \mu \mathrm{L}, 17 \mathrm{mg}, 0.25 \mathrm{mmol})$, and a solution of $\mathrm{NaClO}_{2}(12 \mathrm{mg}, 0.12 \mathrm{mmol})$ and $\mathrm{NaH}_{2} \mathrm{PO}_{4}(32 \mathrm{mg}, 0.6 \mathrm{mmol})$ in water $(1.4 \mathrm{~mL})$ were added. After $1 \mathrm{~h}$ at $0{ }^{\circ} \mathrm{C}$, the reaction was quenched with water $(20 \mathrm{~mL})$ and diluted with EtOAc $(20 \mathrm{~mL})$. The layers were separated and the aqueous phase was extracted with EtOAc $(3 \times 10 \mathrm{~mL})$. The combined organic layers were dried over $\mathrm{MgSO}_{4}$ and concentrated. The residue was purified on silica gel $\left(\mathrm{CH}_{2} \mathrm{Cl}_{2} / \mathrm{MeOH}, 95: 5\right)$ to afford $20 \mathrm{mg}$ (91\%) of acid 34 as a yellowish oil: $\mathrm{R}_{f}$ (hexanes/EtOAc, 7:3) $0.15 ;[\alpha]_{\mathrm{D}}-10.5(c$ 0.96, $\mathrm{CHCl}_{3}$ ); IR 3448, 2927, 2855, 1734, 1711, 1462, 1424, 1377, 1238, 1109, 1038, 704; ${ }^{1} \mathrm{H}$ NMR 0.83 (d, $\left.J=6.6,3 \mathrm{H}\right), 1.08$ (s, $\left.9 \mathrm{H}\right), 1.22(\mathrm{~d}$, $J=7.0,3 \mathrm{H}), 1.23-1.33(\mathrm{~m}, 2 \mathrm{H}), 1.43(\mathrm{~s}, 6 \mathrm{H}), 1.42-1.91(\mathrm{~m}, 5 \mathrm{H}), 1.70(\mathrm{~s}, 3 \mathrm{H}), 1.87-2.04(\mathrm{~m}, 3 \mathrm{H}), 2.68(\mathrm{dd}, J=13.8,3.6,1 \mathrm{H}), 2.74(\mathrm{~d}, J=7.1$, 2H), 3.17-3.28 (m, 1H), 3.25 (s, 3H), 3.40-3.53 (m, 1H), 3.68-3.78 (m, 2H), 3.98-4.10 (m, 3H), 4.50-4.57 (m, 2H), $4.69(\mathrm{~s}, 1 \mathrm{H}), 4.74(\mathrm{~s}, 2 \mathrm{H})$, $4.89(\mathrm{~s}, 1 \mathrm{H}), 5.38(\mathrm{dd}, J=15.3,7.41 \mathrm{H}), 5.51-5.68(\mathrm{~m}, 2 \mathrm{H}), 5.70-5.79(\mathrm{~m}, 2 \mathrm{H}), 5.98(\mathrm{~d}, J=15.8,1 \mathrm{H}), 6.16(\mathrm{dd}, J=14.7,10.4,1 \mathrm{H}), 6.26(\mathrm{dd}, J$ $=15.0,10.4,1 \mathrm{H}), 7.33-7.43(\mathrm{~m}, 6 \mathrm{H}), 7.66-7.76(\mathrm{~m}, 4 \mathrm{H}) ;{ }^{13} \mathrm{C}$ NMR 16.1, 17.0, 19.7, 22.5, 27.0, 27.1, 27.3, 27.8, 29.1, 31.1, 35.0, 35.4, 36.4, 
$41.4,42.5,55.6,77.9,78.2,79.3,81.7,82.2,82.4,97.2,108.8,110.8,115.1,125.5,127.5,127.6,127.7,128.5,129.7,129.7,130.7,133.1$, 133.4, 133.7, 133.8, 133.9, 136.2, 136.4, 136.7, 144.6, 144.7, 176.9; HRMS (ESI-) calcd for $\mathrm{C}_{51} \mathrm{H}_{71} \mathrm{O}_{8} \mathrm{Si}^{-}(\mathrm{M}-\mathrm{H})^{-} 839.4924$, found 839.4934.

Hydroxy acid 35 (seco-acid 35). A 1 M solution of TBAF in THF (42 $\mu \mathrm{L}, 0.042 \mathrm{mmol})$ was added to a solution of acid 34 (12.0 mg, 0.014 mmol) in THF $(0.5 \mathrm{~mL})$ under Ar at $0{ }^{\circ} \mathrm{C}$. The reaction was stirred at $50{ }^{\circ} \mathrm{C}$ for $2 \mathrm{~h}$. Again, TBAF $(1 \mathrm{M}$ in $\mathrm{THF}, 42 \mu \mathrm{L}, 0.042 \mathrm{mmol})$ was injected and the mixture was stirred for $2 \mathrm{~h}$. Finally, the last portion of TBAF ( $28 \mu \mathrm{L}, 0.028$ mmol) was added. Two hours later the crude reaction mixture was filtered through a short path of silica (hexanes/EtOAc/AcOH, 1:1:0.01). After careful evaporation, the residue was purified on silica gel $\left(\mathrm{CHCl}_{3} / \mathrm{MeOH} 95: 5\right)$ to recover starting material (5.5 $\mathrm{mg}$ of 34, which was subjected to deprotection, again) and to isolate seco-acid 35 (4.3 mg, 50\%) as a colorless oil: $\mathrm{R}_{f}\left(\mathrm{CHCl}_{3} / \mathrm{MeOH}, 95: 5\right)$ 0.3; ${ }^{1} \mathrm{H}$ NMR $0.85(\mathrm{~d}, J=6.5,3 \mathrm{H}), 1.27(\mathrm{~d}, J=7.0,3 \mathrm{H}), 1.32-1.37(\mathrm{~m}$, $1 \mathrm{H}), 1.43(\mathrm{~s}, 6 \mathrm{H}), 1.46-1.54(\mathrm{~m}, 2 \mathrm{H}), 1.71(\mathrm{~s}, 3 \mathrm{H}), 1.74-1.84(\mathrm{~m}, 2 \mathrm{H}), 1.86-1.95(\mathrm{~m}, 3 \mathrm{H}), 2.00-2.10(\mathrm{~m} 1 \mathrm{H}), 2.17-2.25(\mathrm{~m}, 1 \mathrm{H}), 2.76(\mathrm{~d}, J=$ 7.0, 2H), 2.90-2.98 (m, 1H), 3.10-3.19 (m, 1H), $3.24(\mathrm{~d}, J=10.2,1 \mathrm{H}), 3.37(\mathrm{~s}, 3 \mathrm{H}), 3.62(\mathrm{~d}, J=7.6,1 \mathrm{H}), 3.70-3.76(\mathrm{~m}, 1 \mathrm{H}), 3.95-4.06(\mathrm{~m}$, $3 \mathrm{H}), 4.69(\mathrm{~d}, J=6.7,1 \mathrm{H}), 4.69(\mathrm{~s}, 1 \mathrm{H}), 4.73(\mathrm{~s}, 1 \mathrm{H}), 4.88(\mathrm{~s}, 1 \mathrm{H}), 4.99(\mathrm{~s}, 1 \mathrm{H}), 5.03(\mathrm{~d}, J=6.8,1 \mathrm{H}), 5.38(\mathrm{dd}, J=14.9,7.4,1 \mathrm{H}), 5.55(\mathrm{dd}, J=$ $14.7,7.8,1 \mathrm{H}), 5.61-5.79(\mathrm{~m}, 3 \mathrm{H}), 6.06(\mathrm{~d}, J=15.5,1 \mathrm{H}), 6.13-6.23(\mathrm{~m}, 2 \mathrm{H}) ;{ }^{13} \mathrm{C}$ NMR 15.7, 17.3, 22.6, 27.2, 27.3, 28.3, 29.1, 30.1, 34.5, 34.9, $36.1,41.5,43.3,56.4,76.9,78.7,79.0,80.5,82.4,82.4,97.2,109.1,110.9,115.6,126.1,128.0,128.4,130.9,133.7,134.0,134.1,137.1,144.8$, 145.0, 182.8 (see Supporting Information; almost all the ${ }^{13} \mathrm{C}$ signals of our sample are $0.2 \mathrm{ppm}$ at higher field than those reported, ${ }^{4}$ but we used $\mathrm{CDCl}_{3}$ as the internal reference, $\delta 77.0 \mathrm{ppm}$, whereas TMS was employed in ref 4); HRMS (ESI-) calcd for $\mathrm{C}_{35} \mathrm{H}_{53} \mathrm{O}_{8}{ }^{-}(\mathrm{M}-\mathrm{H})^{-} 601.3746$, found 601.3739. The assignments of the NMR signals were confirmed by a standard HSQC experiment.

\section{ASSOCIATED CONTENT}

\section{Supporting Information}

Copies of ${ }^{1} \mathrm{H}$ NMR and ${ }^{13} \mathrm{C}$ NMR spectra of the new compounds and of $\mathbf{3 5}$. The Supporting Information is available free of charge on the ACS Publications website at DOI: $10.1021 /$ acs.joc.........

\section{AUTHOR INFORMATION}

\section{Corresponding Authors}

*E-mail: amcosta@ub.edu (A.M.C.)

*E-mail: jvilarrasa@ub.edu (J.V.)

\section{Notes}

The authors declare no competing financial interest.

\section{ACKNOWLEDGMENTS}

Grants CTQ2006-15393, CTQ2009-13590, CTQ2012-39230, and CTQ2015-71506-R (Spanish Government, FEDER), and 2009SGR825 (AGAUR, Barcelona) are acknowledged. L.B., a postdoc in our group (CTQ2015) during 2016, carried out the 
optimization of the allyl sulfide to allyl sulfone reaction and the synthesis of additional amounts of the northern fragment, as well as the repetition of the last six steps of the sequence in collaboration with E.P. (fellow of the Fundació Cellex during 2017). L.M. was an UB PhD student (her Doctorate Thesis was defended on 28 June 2016). M.S. was a Master student (2015-2016) who performed the asymmetric epoxidation studies. J.E., an UB PhD student (2004-2008) and later a fellow of the Fundació Cellex (April 2009March 2010), began the project in the fall of 2005. The participation of undergraduate students Guillem Vázquez (2013) and Cristian Marco (2014) in an approach to 17 (fragment C10-C17) via hydrolytic kinetic resolution of the corresponding intermediate epoxides also deserves to be mentioned. Useful information from Prof. Albrecht Berkessel (Universität zu Köln) and a gift of the new binaphthyl analog of salalen (Scheme 7) are deeply acknowledged. This work is dedicated to the late President of the Fundació Cellex of Barcelona, chemist and entrepreneur, Dr. Pere Mir (deceased 10 March 2017).

\section{REFERENCES}

(1) (a) Kobayashi, J. J. Antibiot. 2008, 61, 271-284. (b) Kobayashi, J.; Kubota, T. J. Nat. Prod. 2007, 70, 451-460. (c) Kobayashi, J.; Tsuda, M. Nat. Prod. Rep. 2004, 21, 77-93. (d) Sharma, G. V. M.; Doddi, V. R. In Natural Lactones and Lactams; Janecki, T., Ed.; WileyVCH: Weinheim, 2014; pp 229-272.

(2) (a) Rodríguez-Escrich, C.; Urpí, F.; Vilarrasa, J. Org. Lett. 2008, 10, 5191-5194 (amphidinolide X). (b) Trigili, C.; Pera, B.; Barbazanges, M.; Cossy, J.; Meyer, C.; Pineda, O.; Rodríguez-Escrich, C.; Urpí, F.; Vilarrasa, J.; Díaz, J. F.; Barasoain, I. ChemBioChem 2011, 12, 1027-1030 (X and J, actin). (c) Mola, L.; Olivella, Urpí, F.; Vilarrasa, J. Tetrahedron Lett. 2014, 55, 900-902. (amphidinolide Y) (d) Sánchez, D.; Andreou, T.; Costa, A. M.; Meyer, K. G.; Williams, D. R.; Barasoain, I.; Díaz, J. F.; Lucena-Agell, D.; Vilarrasa, J. J. Org. Chem. 2015, 80, 8511-8519 (amphidinolide K, actin). (e) Sidera, M. "Aproximació a la síntesi total d'una macròlida citotòxica: amfidinolida $\mathrm{B}_{1}$; PhD Thesis; Universitat de Barcelona, 2011. (f) Carrillo, J. "Síntesis de la anfidinolida B2"; PhD Thesis; Universitat de Barcelona, 2015.

(3) (a) Kobayashi, J.; Ishibashi, M.; Murayama, T.; Takamatsu, M.; Iwamura, M.; Ohizumi, Y.; Sasaki, T. J. Org. Chem. 1990, 55, 34213423. (b) Kubota, T.; Tsuda, M.; Kobayashi, J. J. Org. Chem. 2002, 67, 1651-1656.

(4) (a) Kim, C. H.; An, H. J.; Shin, W. K.; Yu, W.; Woo, S. K.; Jung, S. K.; Lee, E. Angew. Chem., Int. Ed. 2006, 45, 8019-8021. (b) Kim, C. H.; An, H. J.; Shin, W. K.; Yu, W.; Woo, S. K.; Jung, S. K.; Lee, E. Chem. Asian J. 2008, 3, 1523-1534.

(5) (a) Va, P.; Roush, W. R. J. Am. Chem. Soc. 2006, 128, 15960-15961. For syntheses of stereoisomers of 1, see: (b) Va, P.; Roush, W. R. Org. Lett. 2007, 9, 307-310. (c) Va, P.; Roush, W. R. Tetrahedron 2007, 63, 5768-5796.

(6) (a) Gurjar, M. K.; Mohapatra, S.; Phalgune, U. D.; Puranik, V. G.; Mohapatra, D. K. Tetrahedron Lett. 2004, 45, 7899-7902 (C12C29). (b) Marshall, J. A.; Schaaf, G.; Nolting, A. Org. Lett. 2005, 7, 5331-5333 (C6-C21). (c) Esteban, J.; Costa, A. M.; Gómez, A.; Vilarrasa, J. Org. Lett. 2008, 10, 65-68 (C1-C5). (d) Esteban, J.; Costa, A. M.; Vilarrasa, J. Org. Lett. 2008, 10, 4843-4846 (C10-C26). (e) Mohapatra, S.; Nayak, S.; K. Mishra, S.; Pattanaik, P. Lett. Org. Chem. 2013, 10, 65-69 (C1-C9, C10-C18).

(7) For reviews of the several variants of Julia olefination, see: (a) Blakemore, P. R. J. Chem. Soc. Perkin Trans. 1 2002, 2563-2585. (b) Aïssa, C. Eur. J. Org. Chem. 2009, 1831-1844. Also see: (c) Alonso, D. A.; Fuensanta, M.; Gómez-Bengoa, E.; Nájera, C. Eur. J. Org. Chem. 
2008, 2915-2922, and refs cited therein.

(8) Billard, F.; Robiette, R.; Pospíšil, J. J. Org. Chem. 2012, 77, 6358-6364.

(9) For the construction of the C5-C6 double bond we initially examined the J-K reaction between the phenyl tetrazolyl sulfone derived from TBDPS-monoprotected $(4 R, 5 R)$-2,3-O-isopropylidenethreitol (prepared from reduction of diethyl $(S, S)$-tartrate, monoprotection as a TBDPS ether, Mitsunobu reaction with 1-phenyl-1H-tetrazole-5-thiol (PT-SH), and oxidation of the thioether to the corresponding phenyltetrazole-sulfone (PT$\mathrm{SO}_{2} \mathrm{R}$ ) and the aldehyde obtained by Dess-Martin oxidation of $\mathbf{5}$ (see the main text and reference $6 \mathrm{c}$ ). Although the $\mathrm{J}-\mathrm{K}$ reaction of aliphatic sulfones with $\alpha, \beta$-unsaturated aldehydes is well-documented, ${ }^{7}$ the $E$ isomer being consistently obtained, initial control experiments determined that our aliphatic sulfone decomposed when treated with KHMDS (probably via $\beta$-elimination), but remained unchanged when NaHMDS or LiHMDS were used (THF, $-78^{\circ} \mathrm{C}, 2 \mathrm{~h}$ ). Moreover, while the $\mathrm{J}-\mathrm{K}$ reactions of the sodium salt of this sulfone with cinnamaldehyde or acrolein gave high yields and complete stereoselectivity of the expected products, the reaction with the aldehyde derived from $\mathbf{5}$ did not afford the expected diene. Analysis by ${ }^{1} \mathrm{H}$ NMR of the crude product mixtures revealed the presence of substantial amounts of unreacted sulfone. Probably, the aldehyde (with a relatively acidic hydrogen at $\mathrm{C} 2)$ is too unstable under the reaction conditions.

(10) McDougal, P. G.; Rico, J. G.; Oh, Y.-I.; Condon, B. D. J. Org. Chem. 1986, 51, 3388-3390.

(11) (a) Blakemore, P. R.; Cole, W. J.; Kocienski, P. J.; Morley, A. Synlett 1998, 26-28. For reviews, see ref 7 and (b) Plesniak, K.; Zarecki, A.; Wicha, J. Top. Curr. Chem. 2007, 275, 163-250.

(12) (a) Evans, D. A.; Andrews, G. C. Acc. Chem. Res. 1974, 7, 147-155. (b) Hilpert, H.; Wirz, B. Tetrahedron 2001, 57, 681-694. (c) Bastin, R.; Dale, J. W.; Edwards, M. G.; Papillon, J. P. N.; Webb, M. R.; Taylor, R. J. K. Tetrahedron 2011, 67, 10026-10044, and refs cited therein.

(13) The epimerization (at C7) of the aldehyde under the reaction conditions was also considered, but the practically identical chemical shifts of the isopropylidene methyl groups suggested that the trans-dioxolane substructure was maintained. See: Chuche, J.; Dana, G.; Monot, M. R. Bull. Soc. Chim. Fr. 1967, 3300-3307. Migrations of the double bonds are also feasible, but they were not observed.

(14) (a) Thomas, E. J.; Willis, M. Org. Biomol. Chem. 2014, 12, 7537-7550. (b) Sasaki, K.; Urabe, D.; Arai, H.; Arita, M.; Inoue, M. Chem. Asian J. 2011, 6, 534-543. (c) Domínguez, M.; Álvarez, S.; Álvarez, R.; Rodríguez de Lera, A. Tetrahedron 2012, 68, $1756-1761$.

(15) Pospíšil, J. Tetrahedron Lett. 2011, 52, 2348-2352.

(16) Pilli, R. A.; Riatto, V. B. Tetrahedron: Asymmetry 2000, 11, 3675-3686.

(17) (a) Berkessel, A.; Günther, T.; Wang, Q.; Neudörfl, J.-M. Angew. Chem. Int. Ed. 2013, 52, 8467-8471. (b) Berkessel, A.; Ong, M.-C.; Nachi, M.; Neudörfl, J.-M. ChemCatChem 2010, 2, 1215-1218; (c) Wang, Q.; Neudörfl, J.-M.; Berkessel, A. Chem. Eur. J. 2015, 21 , $247-254$.

(18) Mancuso, A. J.; Huang, S.-L.; Swern, D. J. Org. Chem. 1978, 43, 2480-2482.

(19) The Jacobsen hydrolytic kinetic resolution of epoxide $( \pm)-\mathbf{1 4}$ and of a diastereomeric mixture of epoxides obtained in $90 \%$ yield by treatment of the $4-O$-TBS derivative of 15 with $3-\mathrm{ClC}_{6} \mathrm{H}_{4} \mathrm{CO}_{3} \mathrm{H}$ gave practically enantiopure epoxides (in $42-45 \%$ yields). (a) The ( $R, R$ )(salen)Co ${ }^{\mathrm{III}}$ OTs catalyst was prepared according to: (a) Stevenson, C. P.; Nielsen, L. P. C; Jacobsen, E. N.; McKinley, J. D.; White, T. D.; Couturier, M. A.; Ragan, J. Org. Synth. 2006, 83, 162-169. (b) For the mechanism, see: Nielsen, L. P. C.; Zuend, S. J.; Ford, D. D.; Jacobsen, E. N. J. Org. Chem. 2012, 77, 2486-2495.

(20) (a) Fuwa, H.; Nakajima, M.; Shi, J.; Takeda, Y.; Saito, T.; Sasaki, M. Org. Lett. 2011, 13, 1106-1109. (b) We prepared 18 in five 
simple steps from $(R)$-glycidol, namely, $O$-benzylation, addition of vinylmagnesium bromide (catalyzed by $\mathrm{CuI}$ ), protection with $\mathrm{TBSCl}$, hydroboration/oxidation, and Swern oxidation (all yields $>90 \%$ ). These synthetic intermediates were known compounds.

(21) (a) Evans, D. A.; Bender, S. L.; Morris, J. J. Am. Chem. Soc. 1988, 110, 2506-2526. (b) Sidera, M.; Costa, A. M.; Vilarrasa, J. Org. Lett. 2011, 13, 4934-4937.

(22) (a) Chatterjee, B.; Bera, S.; Mondal, D. Tetrahedron: Asymmetry 2014, 25, 1-55. (b) Legnani, L.; Porta, A.; Caramella, P.; Toma, L.; Zanoni, G.; Vidari, G. J. Org. Chem. 2015, 80, 3092-3100.

(23) For a general entry to all these standard protection/deprotection schemes, see: Wuts, P. G. M.; Greene, T. W. Protective Groups in Organic Synthesis, 4th ed.; Wiley: Hoboken, 2007; pp 123-130.

(24) (a) Our initial retrosynthetic plan considered esterification of the northern and southern fragments followed by macrocycle formation by either ring-closing metathesis or a J-K reaction. Preliminary experiments showed that Shiina esterification of $(2 R, 3 E, 5 E)-6-[(4 R, 5 R)-5$-(tert-butyldiphenylsilyloxymethyl)-2,2-dimethyl-1,3-dioxolan-4-yl]-2-methyl-3,5-hexadienoic acid (that is, of a fragment C1-C9, see Scheme 1, with C1 in the form of $\mathrm{COOH}$ and $\mathrm{C} 9$ in the form of the $\mathrm{CH}_{2} \mathrm{OTBDPS}$ group) with isopropanol afforded the desired ester but as a 70:30 mixture of epimers at $\mathrm{C} 2$. For the activation of the carboxyl group as its mixed 2-methyl-5-nitrobenzoyl anhydride and ester formation in the presence of DMAP, see: Shiina, I. Chem. Rev.

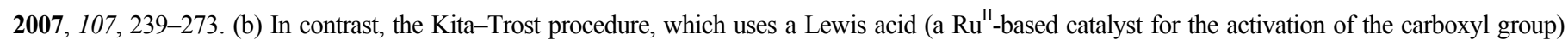
followed by a Brönsted acid (CSA), gave the expected ester in quantitative yield. For the Kita-Trost procedure, see: Ohba, Y.; Takatsuji, M.; Nakahara, K.; Fujioka, H.; Kita, Y. Chem. Eur. J. 2009, 15, 3526-3537, and refs cited therein. (c) However, when this last procedure was applied to the esterification of this acid with the alcohol derived from the PMB deprotection of 27a (see Experimental Section and Supporting Information), no reaction was observed at rt. When the reaction mixture was heated, the acid was recovered unaltered but the alcohol was transformed into the corresponding methylene acetal (derived from an intramolecular transacetalization, with the MOM group). Other esterification methods (Shiina, EDC/HOBt) were also tested, without success.

(25) Lee et al. (ref 4) used LiHMDS in THF at $-78^{\circ} \mathrm{C}$ for the $\mathrm{J}-\mathrm{K}$ reaction of a similar sulfone (which already contained the side chain), with an excess (1.5 equiv) of aldehyde 12 in DMF/DMPU. They obtained a 74\% yield of a 10:1 E/Z mixture. To avoid the appearance of the $Z$ isomer (often a difficult-to-separate byproduct), we insisted on using KHMDS, 18-crown-6, and DMF.

(26) Molander, G. A.; Felix, L. A. J. Org. Chem. 2005, 70, 3950-3956.

(27) Brimble, M. A.; Park, J. H.; Taylor, C. M. Tetrahedron 2003, 59, 5861-5868, and refs cited therein.

(28) Yuasa, Y.; Ando, J.; Shibuya, S. J. Chem. Soc. Perkin Trans. 1 1996, 793-802.

(29) This compound has been reported as a mixture of cis and trans isomers (ca. 1:1): (a) Finch, O. C.; Furkert, D. P.; Brimble, M. A. Tetrahedron 2014, 70, 590-596. (b) Larsen, C. H.; Ridgway, B. H.; Shaw, J. T.; Smith, D. M.; Woerpel, K. A. J. Am. Chem. Soc. 2005, 127, 10879-10884. 